\title{
EXPANDING AND FACILITATING ACCESS TO THE PAUL LEWIS ANDERSON PHOTOGRAPHS AT GEORGE EASTMAN HOUSE
}

\author{
By
}

\section{Andrew G. Murphy}

Bachelor of Arts (Honours), Mount Saint Vincent University, Halifax, 2013

\begin{abstract}
A thesis presented to Ryerson University \&
George Eastman House, International Museum of Photography and Film

In partial fulfillment of the requirements for the degree of

Master of Arts in Film and Photography Preservation and Collections Management
\end{abstract}

Toronto, Ontario, Canada \& Rochester, New York, United States of America, 2015

(C)Andrew G. Murphy 2015 


\section{AUTHOR'S DECLARATION FOR ELECTRONIC SUBMISSION OF A THESIS}

I hereby declare that I am the sole author of this thesis. This is a true copy of the thesis, including any required final revisions, as accepted by my examiners.

I authorize Ryerson University and George Eastman House International Museum of Photography and Film to lend this thesis to other institutions or individuals for the purpose of scholarly research.

I further authorize Ryerson University and George Eastman House International Museum of Photography and Film to reproduce this thesis by photocopying or by other means, in total or in part, at the request of other institutions or individuals for the purpose of scholarly research. I understand that my thesis may be made electronically available to the public. 


\begin{abstract}
Expanding and Facilitating Access to the Paul Lewis Anderson Photographs at George Eastman House
\end{abstract}

Masters of Arts, 2015

Andrew G. Murphy

Film and Photography Preservation and Collections Management

Ryerson University

Paul Lewis Anderson (American, 1880-1956) was a photographer, educator, and writer. His career began in earnest in 1909 and, with only one major interruption, he continued to photograph until 1953. During his lifetime, he wrote many articles and books on Pictorial photography and photographic techniques. He devoted his photographic work to Pictorialism. This thesis brings to light the 492 Paul Lewis Anderson photographs at George Eastman House by expanding access with a collection guide. This guide consists of vital information about Anderson and the photographs, explanations of the photographic processes Anderson used, a listing of the photographs according to box, examples of the inscriptions he used, and a selected bibliography for more information on Anderson. 


\section{ACKNOWLEDGEMENTS}

Nothing in academia is produced in isolation. On this almost year long process, I wish to thank the following people for their enduring support and encouragement. My greatest thanks is to Jamie M. Allen for taking on this project with me as my first reader and main advisor. Our weekly meetings throughout the winter and spring semesters always pushed me to have something to research and discuss each week. I also extend many thanks to Alice Carver-Kubik for agreeing to act as my second reader and for her advice along the way. I thank the entire Department of Photography staff at George Eastman House, and especially I thank Ross Knapper, Will Green, Barbara Galasso, Olivia Arnone, and Lisa Hostetler, Ph.D.

I could not have done this without the support, friendship, and collegiality of Rachel E. Andrews. Together we make the last Ryerson cohort of students at Eastman House, and I could not think of a better person to have shared this time with. I also wish to thank my colleagues at Ryerson, who have always provided encouragement even though I completed this year in a different country. Especially, I thank Carla-Jean Stokes for her candor over these long and sometimes frustrating months. I thank the faculty in the FPPCM program for their support.

I would be remise if I did not mention friends back home in Halifax, Nova Scotia that have always been there for me. I thank Jayme-Lynn Gloade, Kasie Wilcox, Michael Mohan, Brittany Houghton, and Courtney Mrazek. For truly opening my eyes to possibilities of photography I thank Jacob Mailman, Sue Earle, Adrian Fish, and Allen Crooks. For always inspiring me, I thank my former professors and now friends: Corey Slumkoski, Ph.D. and Susan Joudrey, Ph.D.

Last, but certainly not least, I thank my family for their love, unwavering support, and weekly phone calls to help keep my spirits high. 


\section{Table of Contents}

AUTHOR'S DECLARATION FOR ELECTRONIC SUBMISSION OF A THESIS ............................................. ii

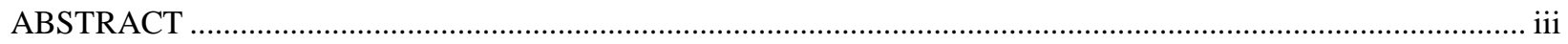

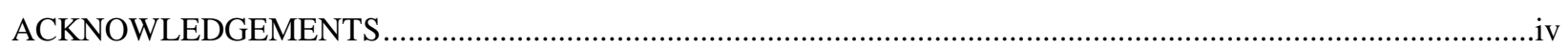

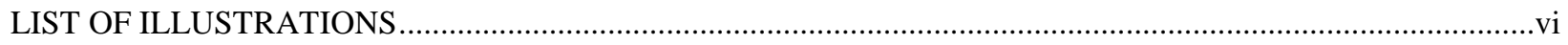

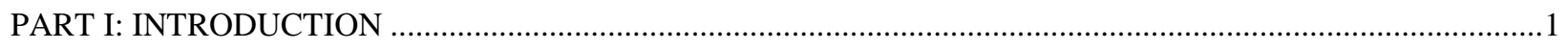

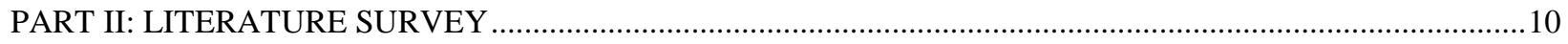

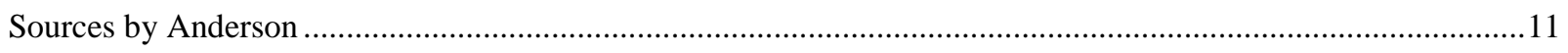

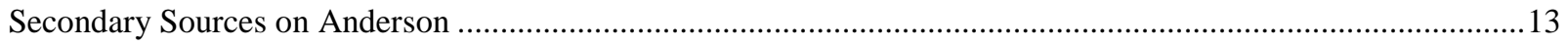

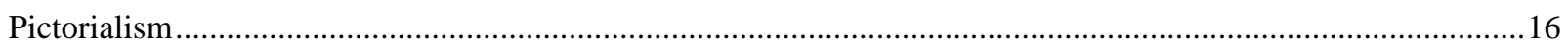

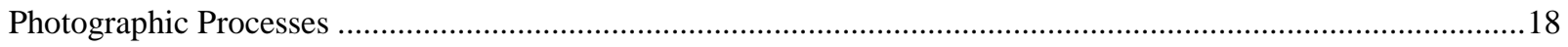

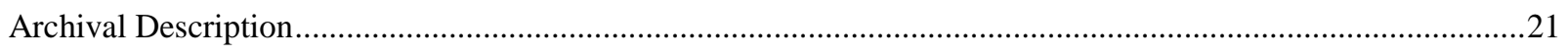

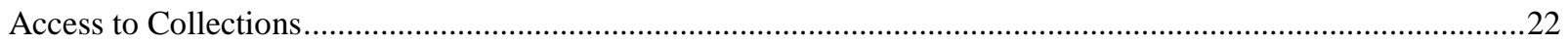

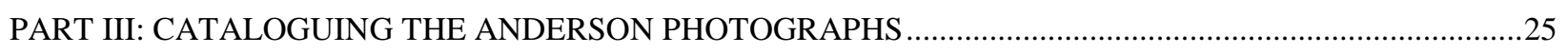

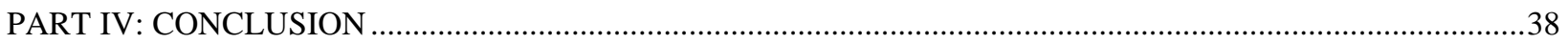

APPENDIX: COLLECITON GUIDE TO THE PAUL LEWIS ANDERSON PHOTOGARPHS AT GEORGE

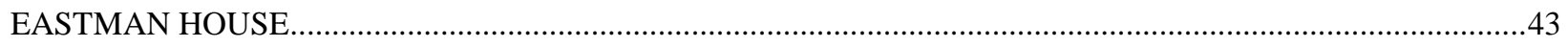

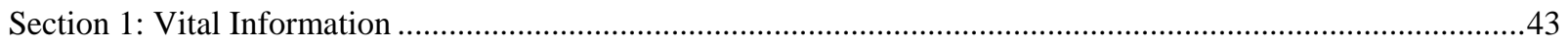

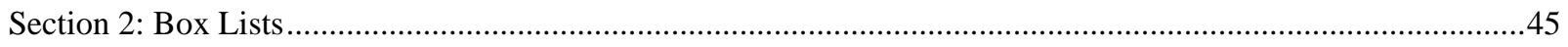

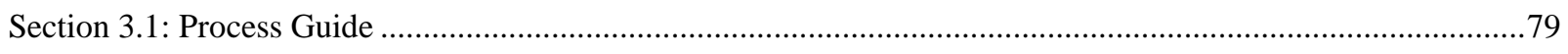

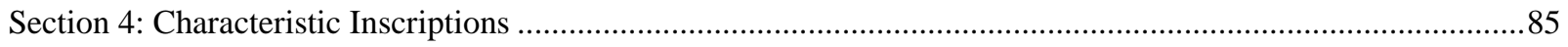

Section 5: Selected Paul Lewis Anderson Bibliography ................................................................................8

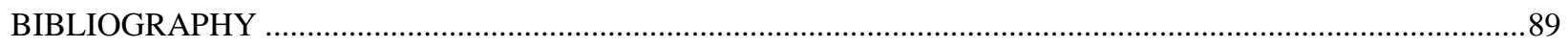




\section{LIST OF ILLUSTRATIONS}

Unless otherwise stated: All works are by Paul Lewis Anderson. All works are held in the collection of George Eastman House; Gift of Mrs. Raymond C. Collins in memory of her father, Paul L. Anderson. All works @ Paul Lewis Anderson, courtesy of Ruth A. Collins.

Illustration 1: Self-Portrait, ca.1911, Platinum print. (1976.0315.0450) ................................................................

Illustration 2 Paradise Road, 1932, Bromoil print (1976.0315.0126) ...................................................................

Illustration 3 Smith College: Paradise Pond, 1932, Palladium print (1976.0315.0127) .............................................

Illustration 4: What do the Critics say? 1938, Gelatin silver print (1976.0315.0457) ................................................10

Illustration 5: Sunday Morning, 1944, Palladium print (1976.0315.0322) .................................................................15

Illustration 6: Shadows and Sun, 1942 Gum bichromate print (1976.0315.0057) ....................................................15

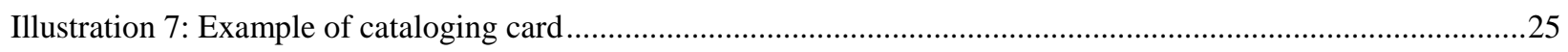

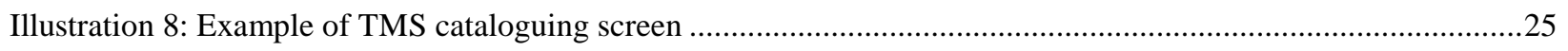

Illustration 9: Portrait of an Artist (Henry R. Poore), 1913, Carbon print (1976.0315.0475)..................................27

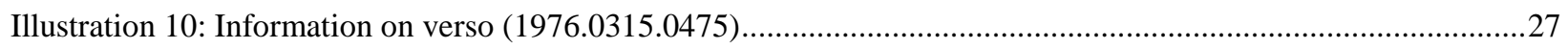

Illustration 11: A Dryad, 1917, Palladium print (1976.0315.0006) …….............................................................28

Illustration 12 Both are the same image yet show different dates. Top: 1976.0315.0126; bottom: 1976.0315.0127..30

Illustration 13: Verso of 1976.0315.0123, showing many different types of inscriptions ...........................................33

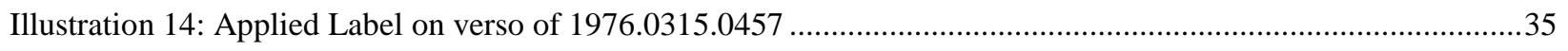

Illustration 15: From my Window, 1951, Palladium print (1976.0315.0017) ……………………………...............38 


\section{LIST OF APPENDICES}

APPENDIX: COLLECITON GUIDE TO THE PAUL LEWIS ANDERSON PHOTOGARPHS AT GEORGE

EASTMAN HOUSE

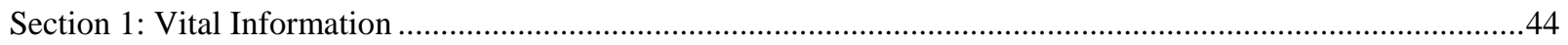

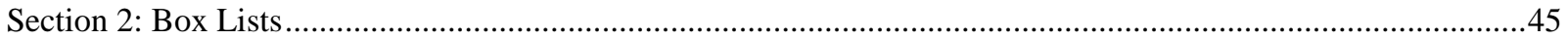

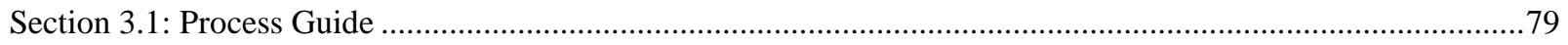

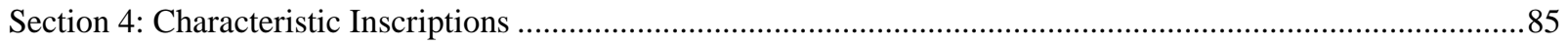

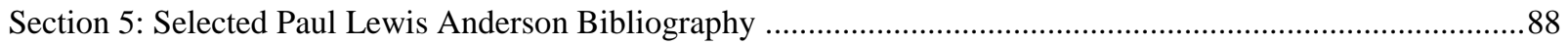




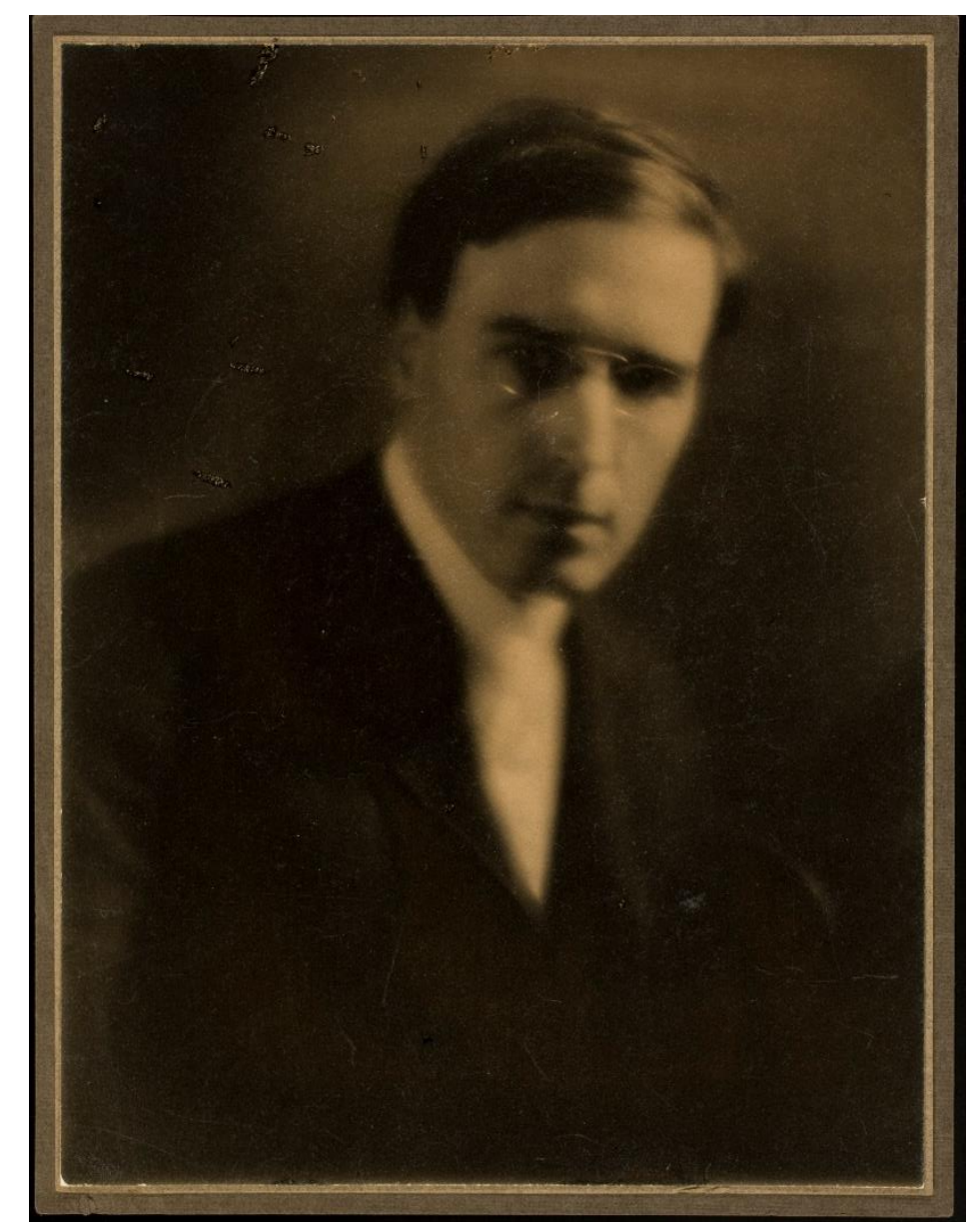

Illustration 1: Self-Portrait, ca.1911, Platinum print. (1976.0315.0450)

\section{PART I: INTRODUCTION}

Paul Lewis Anderson (American, 1880-1956) was born in Trenton, New Jersey. He was an electrical engineer by trade and was not interested in artistic photography when he was first learning the medium. However, after seeing a copy of Camera Work, he quit his job at the New York Telephone Company and took up artistic photography, opening a studio in East Orange, New Jersey in $1910 .{ }^{1}$ For the better part of the next forty years, Anderson worked out of East Orange and photographed his surroundings, and his middle-class family and friends. Anderson

\footnotetext{
${ }^{1}$ Terence R. Pitts, "Paul Lewis Anderson: A Life in Photography," The Archive 18 (May 1983): 5.
} 
also taught courses on photographic techniques for a brief time (1914-1917) at the Clarence White School of Photography. ${ }^{2}$

Throughout his career, he wrote extensively and almost exclusively on Pictorialism. He produced technical and aesthetic articles, and wrote books on pictorial photography. Terence Pitts, a photographic historian and past director of the Center for Creative Photography, notes that although he was not a major artist he was "one of the most visible proponents on Pictorialism and his voluminous output...constitutes one of the most systematic attempts to provide a philosophical and art historical foundation for pictorial aesthetics." ${ }^{3}$ His writings are a window to a specific time and place in both photography and early twentieth-century America. In terms of his reputation during his lifetime, Anderson was never a member of the PhotoSecession though he was aligned with a few organizations throughout his life. ${ }^{4}$ While he was an active contributor to photographic periodicals and submitted work to various exhibitions and salons, he was mostly independent of organized groups.

Anderson was a part of the Pictorialist movement after 1915 until his death in the early 1950s. The standard photographic history sources give the impression that Pictorialism died out as a result of amateur codification of Pictorialist ideals and it was abandoned by artists in favor

\footnotetext{
2 The Clarence White School of Photography was established by the photographer Clarence H. White in 1914. The goal of the institution was to provide an education, both technical and aesthetic, to photographers. The school changed over the years as it embraced new ideas about photography. Even after White's death in 1925, the school remained active until 1942. For more information see Bonnie Yochelson, "The Clarence H. White School of Photography," in Object:Photo. Modern Photographs: The Thomas Walther Collection 1909-1949. An Online Project of The Museum of Modern Art., eds. Mitra Abbaspour, Lee Ann Daffner, and Maria Morris Hambourg (New York: The Museum of Modern Art, 2014), http://www.moma.org/interactives/objectphoto/assets/essays/Yochelson.pdf

3 Pitts, "Paul Lewis Anderson," 5.

${ }^{4}$ He taught from 1914 to 1917 at the Clarence H. White School of Photography in New York City. He was also president and the senior Pictorialist at his hometown Orange Camera Club in the 1940s, though at this time he had become estranged from the mainline Pictorialists (Christian A. Peterson, After the Photo-Secession 172). For more on his estrangement see Christian A. Peterson, After the Photo-Secession: American Pictorial Photography 19101955 (New York: W.W. Norton \& Company, 1997).
} 
of modernism. ${ }^{5}$ This is not entirely true; though Pictorialism was abandoned starting around 1915 by figures such as Edward Weston, Paul Strand, and Alfred Stieglitz, it continued after that time with a new generation of photographers that were members of camera clubs around the United States and the world. In this era Pictorialism was institutionalized, its aesthetics were heavily established by serious amateurs, and it became the standard visual form in many photography periodicals. ${ }^{6}$ Furthermore, this era saw Pictorialism championed by groups of serious avocational "salonists" dedicated to the competent mastery of conventional pictorial processes and techniques. $^{7}$

Anderson fits conveniently into this model of the avocational salonists. He prided himself on his mastery of conventional and advanced processes and techniques, and enjoyed wide dissemination of his writings through photography periodicals. Furthermore, Anderson typifies the duality of the salon culture and amateur Pictorialist movement. On the one hand, he submitted what he deemed artful aestheticized photographs to salons, and on the other he listed and explained the technical data that enabled him to produce those photographs. ${ }^{8}$

Anderson started his career in the turbulent times of 1910-1915 when the PhotoSecession was coming apart, but his career matured and subsisted in the time of the Photographic Society of America (PSA) when amateurs had firmly established a Pictorialist tradition that was an industry unto itself. By the 1930s and 1940s, the PSA was the largest photographic group in the United States, as a large scale institution with many member clubs, exhibitions, and

\footnotetext{
${ }^{5}$ Michael S. Griffin, Amateur Photography and Pictorial Aesthetics: Influences of Organizations and Industry on Cultural Production, PhD Dissertation (Philadelphia: University of Pennsylvania, 1987), 144.

${ }^{6}$ Ibid, 157.

${ }^{7}$ Ibid, 171.

${ }^{8}$ Ibid, 235.
} 


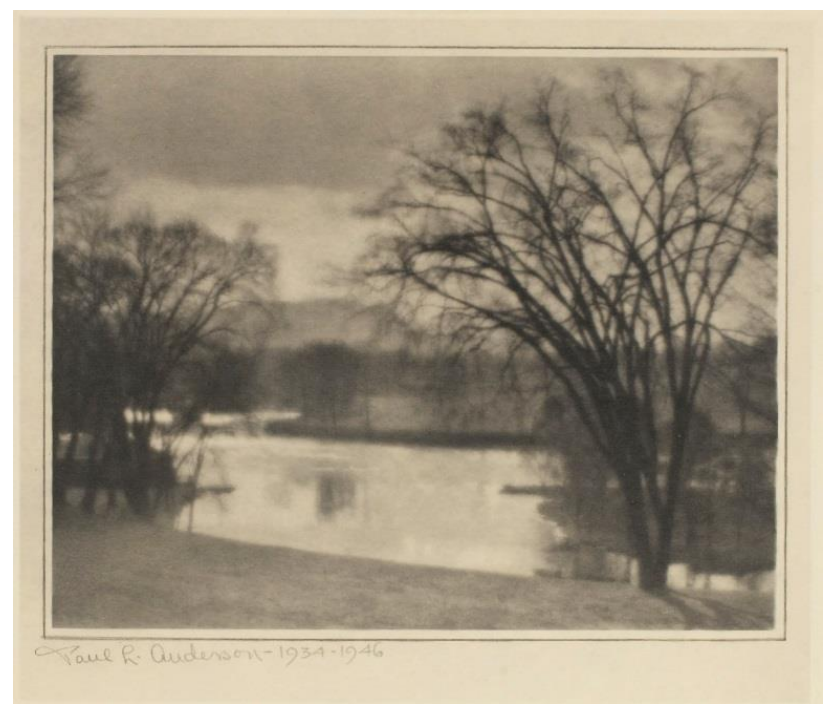

Illustration 3: Paradise Road, 1932, Bromoil print (1976.0315.0126)

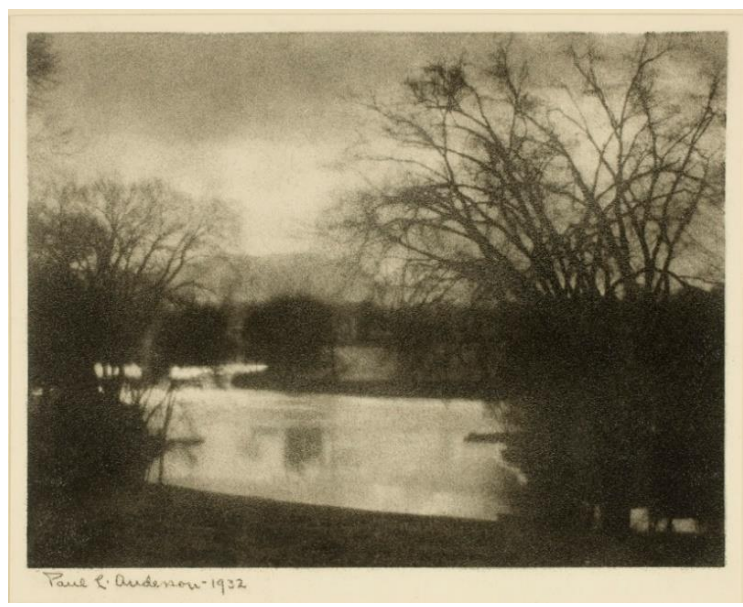

Illustration 2: Smith College: Paradise Pond, 1932, Palladium print (1976.0315.0127)

sub-organizations. ${ }^{9}$ Indeed, the last half of Anderson's career is characterized by an explosion in amateur pictorial photography that continued for the rest of his lifetime and afterwards.

Anderson was a constant experimenter with photographic processes. Throughout his career he worked with a number of different processes, from the obscure to the ubiquitous. For example, he was particularly fond of using the oil and bromoil processes for his landscapes. He used platinum printing for much of his early career and then switched to palladium when platinum became scarce during World War One. He also used the popular bromide and chlorobromide gelatin silver papers of the day. Anderson would often print the same negative but in different processes. This is well represented in the photographs held at George Eastman House (Eastman House). A good example is the photograph titled Paradise Road that appears in five different processes including gelatin silver with gum overlay, gelatin silver, gum bichromate, palladium, and bromoil ${ }^{10}$

\footnotetext{
${ }^{9}$ By 1952 the group had 23 different departments, ranging from international exhibitions to salon rules, and instruction. Ibid, 241.

${ }^{10}$ Alternatively titled Paradise Pond, but same image. See: 1976.0315.0121-27.
} 
This thesis examines Anderson's photographs at Eastman House. The Anderson holdings at Eastman House were acquired in 1976. The donation was the gift of Anderson's daughter Ruth A. Collins of Short Hills, New Jersey. It consisted of Anderson's photographs, the photographs Anderson collected, and part of his darkroom notes in the form of loose pages taken from a binder. $^{11}$

This collection is representative of the arch of the Anderson's career from 1910 to 1953. It consists of 492 photographic objects that have been housed in Solander cases in the Photography Collection vault. They range in size from small, cropped pictures to enlargements made from paper negatives or inter-negatives. ${ }^{12}$ The photographs have been housed in polyester sleeves or mats and separated by process into a total of 22 boxes. The material was paper cataloged in 1978, including information such as title, date and medium but not including dimensions, inscriptions or attributes. Prior to this thesis, this information had not been entered into The Museum System (TMS; the museum's collection management system), and no additional cataloging information was in TMS apart from a selection that appeared in a 2009 Eastman House exhibition entitled TruthBeauty. Overall, the Anderson photographs had untapped potential. There are opportunities for curatorial projects, laboratory experimentation, and to intellectually understand Anderson within the wider context of the history of photography, but before this is undertaken it must be known what is in the collection.

The only other institution with major holdings of Anderson's photographs is the Center for Creative Photography (CCP) at the University of Arizona, Tucson. The CCP has 524 photographs related to Anderson. These holdings appear to mirror those of Eastman House in

\footnotetext{
${ }^{11}$ See: The Paul Lewis Anderson Collection in the Richard and Ronay Menschel Library. Call Number: AR 2015047 Box 41

12 Anderson noted on the verso of the print if a paper negative was used. For instance for Shadow Pattern - Day (1976.0315.0042), he notes on the verso "paper negative directly in camera."
} 
some regards, but it seems that the CCP has more of the photographs associated with Anderson's family that are more akin to snapshots (albeit still printed on platinum or chlorobromide paper). ${ }^{13}$ However, the CCP also received Anderson's personal library, so more of his textual legacy, that is his writings and what he liked to read, is available there. The CCP has also digitized a large number of its collections and this extends to the Anderson collection with a finding aid, list of photographs and an online gallery of all 524 photographs. ${ }^{14}$ In the online gallery, high resolution digital copies of the photographs and the cataloging information (e.g. title, date, medium, and dimensions) associated with each image is available.

An aspect that is also important to the holdings at Eastman House is that as part of the donation by Ruth A. Collins, Eastman House acquired photographs that Anderson collected by other Pictorialist photographers, such as Karl Struss, and H.Y. Summons. Some of this material (photographs by Struss and Brigman) have been separated from the Anderson material, but retain the credit line listing Collins as the donor. The material consists of Christmas albums given to Anderson by his friend H.Y. Summons, a British photographer, along with loose prints by him. The material has been assigned accession numbers and is partially catalogued in TMS. It is beyond the scope of this present study to examine this material, but it is noted that these materials are in need of cataloguing and understanding. Hopefully, with the increased access created with this thesis to the works by Anderson, these related works will be catalogued in due time.

\footnotetext{
${ }^{13}$ For an inventory of the images CCP has see: "Paul Lewis Anderson: Photograph Collection," (An alphabetical index to the photographs in the Center for Creative Photography Photograph Collection organized by name of photographer), (Tucson: Center for Creative Photography, 2001).

${ }^{14}$ Center for Creative Photography, "Paul L. Anderson," (accessed June 14 ${ }^{\text {th }} 2015$ ) http://ccpemuseum.catnet.arizona.edu/view/people/asitem/items@:65
} 
Access is a pathway to knowledge. It allows for the conditions to be in place that encourage inquiry by all interested individuals. The idea of access is engrained in the Eastman House mission statement. It states, "we convene a global community to share access and understanding of photographs and motion pictures as objects and ideas that inspire discovery and understanding of individuals, cultures, values, and history." ${ }^{15}$ In museum collections, access can be provided through physical means (by having objects safely available to researchers) and by intellectual means (by having items properly catalogued and accessible in a collections management system). In the case of the Anderson collection, access is facilitated by the Department of Photography collections manager at the Gannett Foundation Photographic Study Center.

Additionally, access to institutional collections can be expanded in many ways. It can be expanded by physical means, with the proper housing, encapsulation, or protection for an object that allows a researcher to handle an object safely and effectively. Physical access could also mean the arrangement of a group of objects. For instance, there are boxes dedicated to subjects where objects have been pulled from multiple sources to make an easily accessible collection that can be shown to researchers. By grouping similar objects, the photographs become an easy way to provide to researchers with a variety of examples.

Access can also be expanded through institutional means, such as the proper description and cataloguing of objects. This ensures that something can be searched for and retrieved with relative ease. It also ensures that objects are recorded and different departments (i.e. registration or conservation) are aware of what is in the collection and can track events related to those objects (i.e. acquisition or conservation treatment).

\footnotetext{
${ }^{15}$ Eastman House, "Vision and Mission," accessed June 14, 2015, http://www.eastmanhouse.org/museum/mission.php
} 
Increased access is also facilitated by intellectual means. This may include published or unpublished sources that are available to the prospective researcher. These sources could be an exhibition, a monograph or other book about a subject or reference resources available in a library. This type of access, along with institutional information, is increased by having materials available online, opening up a whole new frontier where information can be easily accessed all around the world.

Since Eastman House is one of only two major institutions that have significant holdings of Anderson materials, and since the photographs were uncatalogued, this practical thesis project aimed to increase both institutional and physical access to the Anderson photographs by fully cataloguing the objects using the museum's collections management system, TMS. This included entering the relevant data about title, date, dimensions, subject, materials, and inscriptions into the individual records. This also included linking related objects together so the relationships (in terms of subjects of the photographs, exhibitions it may have been in, or related images) are clear. This portion of the project allowed previously underutilized materials to have increased access, as both staff and researchers would be better able to search and understand the holdings. Additionally, intellectual access was needed for the public consumption, so a collection guide was created. The guide is an introduction to Anderson for an interested researcher or member of the public. This document, and indeed, this thesis provide the relevant information as a point of departure for further examination of Anderson.

The written portion of this thesis is divided into four parts: part one being this introduction to the Paul Lewis Anderson photographs, a historical contextualization, and how access can be expanded in museums and with these photographs; part two is a literature survey; part three describes my process and how I went about making the collection guide; finally, in my 
conclusion I suggest ways to further access to these materials. Also, the thesis is supplemented by appropriate appendices, including the collection guide, process guide, box lists, and other important information related to Anderson. Through this process access to these materials was increased and light was shed on a lesser known photographer in the George Eastman House collection. As such, the work of Paul Lewis Anderson can now be used as a valuable teaching tool for those interested in photographic processes and Pictorialism into the 1940s. Rather than investigating this era in Pictorialism through written sources, a researcher can access and learn through the Paul Lewis Anderson photographs. 


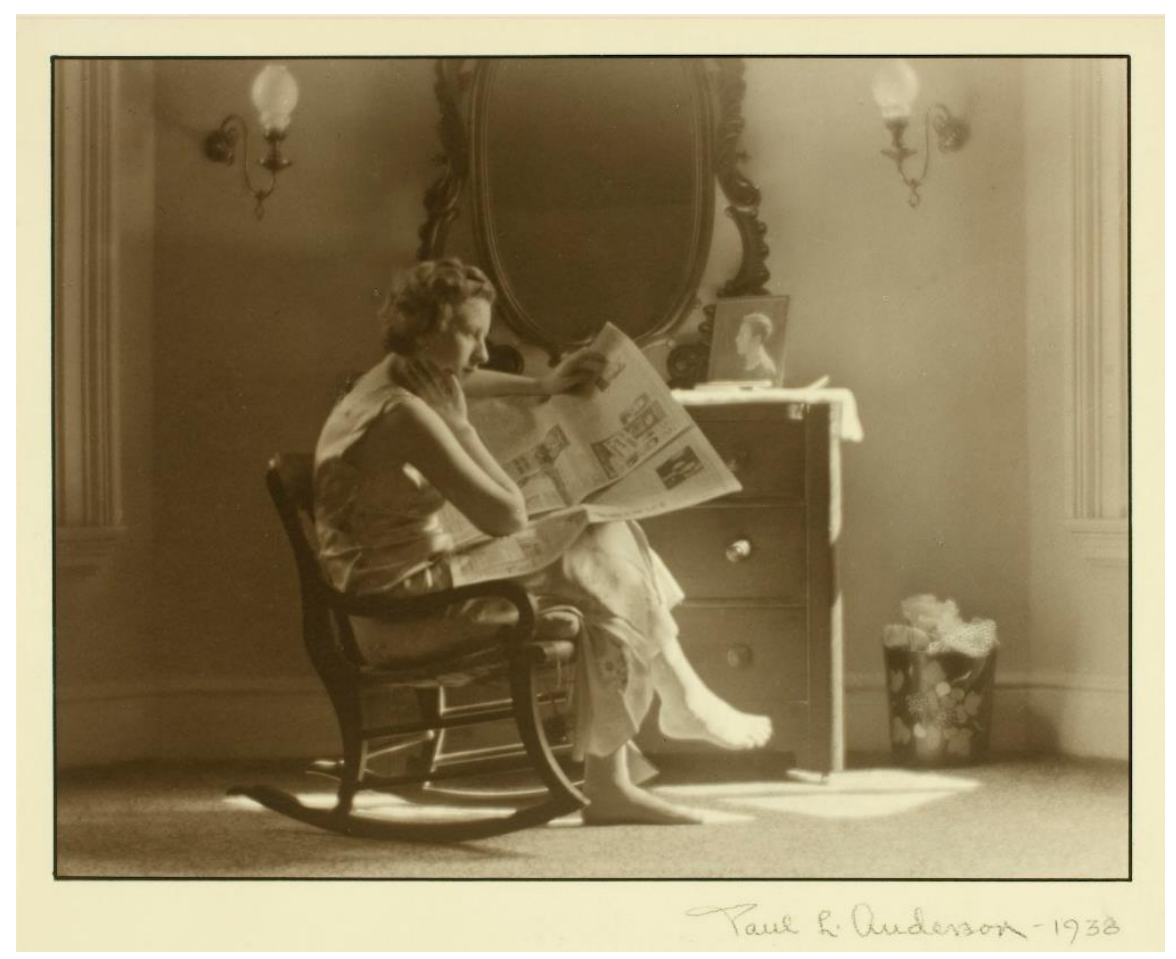

Illustration 4: What do the Critics say? 1938, Gelatin silver print (1976.0315.0457)

\section{PART II: LITERATURE SURVEY}

The literature surrounding Paul Lewis Anderson is vast: in his time he wrote three books on pictorial techniques as well as articles on photographic techniques and criticism that appear in some of the popular, but more conservative, journals of the early twentieth century. ${ }^{16}$ In terms of later texts written about him, there is only one thoughtfully written and critical article: "Paul Lewis Anderson: A Life in Photography." ${ }^{17}$ One can find traces of him in books on Pictorialism, but there are no dedicated monographs on Anderson. ${ }^{18}$ This has meant gathering sources from a variety of categories to make a cohesive structure to inform this thesis on Anderson. This

\footnotetext{
${ }^{16}$ Terrance Pitts states that the journals that Anderson contributed to, The American Annual of Photography and Photograms of the Year, took a conservative approach to art and photography. Pitts, Paul Lewis Anderson: A Life in Pictures," 9.

${ }^{17}$ Terrance Pitts, "Paul Lewis Anderson: A Life in Photography,” The Archive 18 (May 1983).

${ }^{18}$ For instance, he has been included in Truth/Beauty: Pictorialism and the Photograph as Art, 1845-1945, but the only mention of him is in a brief biography included as appendices. He is also mentioned, but only in a fleeting reference, in A History of Photography: 1839 to the Present, ed. Therese Mulligan and David Wooters (New York: Taschen, 2008), 426-429.
} 
literature review examines and critically evaluates the literature surrounding Paul Lewis Anderson and the writings that have helped shape this thesis. Starting with the works written by Anderson and on him, and then expanding to Pictorialism and the photographic processes he used, I contextualize the literature and assess its value to my thesis. I also examine sources written about describing and expanding access to collections to further inform my thesis.

\section{Sources by Anderson}

Anderson was a prolific writer and wrote extensively on photography, Pictorialism, aesthetics, and modern art. His writings fall into two main categories: first, he wrote in-depth about photographic techniques and the various processes that he used and taught; second, Anderson wrote opinion pieces about how he viewed photographic theory, and particularly about how he viewed pictorial and artistic photography. ${ }^{19}$ This adds another dimension to Anderson because not only do we have access to his photographic body of work, but we also have access to a large body of writing that he produced during his career. This gives a view of what informed his practice and what was important to him during a certain period in his career. We can also extrapolate the arch of his career because he wrote prodigiously for a decade or so and then did not write for a number of years. In 1925 he wrote an article for The American Annual of Photography about his values, yet he does not write his next article until 1933 - a hiatus of 8 years.

Apart from frequently appearing in journals, Anderson wrote four books on Pictorialism. ${ }^{20}$ His books allowed him a larger forum to discuss his techniques and for the reader

\footnotetext{
${ }^{19}$ Anderson also wrote nine young adult novels, mostly set in Roman times, but these are beyond the scope of this thesis.

${ }^{20}$ Each book went through at least one edition, except for The Technique of Pictorial Photography (Lippincott, 1939).
} 
to gain a better idea of how Anderson treated longer technical explanations with the aid of diagrams and illustrations. His books are mostly technical and discuss the photographic processes that he uses at-length and serve as a guide for amateur photographers looking to experiment with these processes. For instance, in Pictorial Photography: Its Principles and Practices he writes a study of Pictorialist printing techniques "without wishing to undertake a study of the abstruse scientific phases of the art." ${ }^{21}$ Anderson is writing for the amateur and wants to impart his knowledge in the most accessible way. While Anderson's Pictorial Photography was reviewed in Review of Reviews, this review is an overview of the work and does not offer a critique of the book. ${ }^{22}$ I was unable to find reviews of the book appearing in Pictorialist magazines. Some evidence of its reputation can be gained from the fact that it was published in three editions with revisions, and this book was also reprinted with a new title, The Technique of Pictorial Photography, in 1939. ${ }^{23}$

Anderson's writings are invaluable because they provide written evidence and insight into his practice. His writings also point to his need to educate because much of his writings are instructional. Anderson is detailed in this writing and in many of the books he devotes several pages to step-by-step instructions for processes. When read critically, the reader can see the underlying ideology and his views that are underpinning how he is writing about photography. Along with his photographs, his writings provide another way to examine Anderson.

\footnotetext{
${ }^{21}$ Paul Lewis Anderson, Pictorial Photography: Its Principles and Practices (Philadelphia: Lippincott, 1922$), 7$. 22 "Art and Its Masters," Review of Reviews 61.1 (January 1920), 110.

${ }^{23}$ The book was revised in 1923 and 1934 and then given its new title in 1939.
} 


\section{Secondary Sources on Anderson}

There are a few secondary sources written about Anderson. As was stated in the introduction, the CCP is the only other institution with substantial Anderson holdings. Their journal, The Archive, devoted an issue to discussing the acquisition of the Paul Lewis Anderson materials. Terrance Pitts, a scholar and then librarian at CCP, gives a contextual and critical essay about Anderson and his life in Pictorialism. Pitts is especially critical of Anderson after World War One in the 1920s and 1930s. ${ }^{24}$ He highlights how Anderson became increasingly staunch and unbending in his views on Pictorialism and challenges the artistic views of Modernism. Pitts characterizes Anderson as a photographer who refuses to change and becomes isolated in his later years. ${ }^{25} \mathrm{He}$ uses Anderson's writings as a main point of departure for examining the photographer. In this way Pitts drew directly from the texts that Anderson wrote and found some especially poignant quotes that he uses to critique Anderson and support his arguments.

The publication of this issue of The Archive coincided with an exhibition of Anderson's work at CCP. The journal also reproduces a selection of Anderson's photographs. In addition, an exhibition catalogue provides more discussion of Anderson and shows a curated selection of his work. ${ }^{26}$ The journal also includes a thorough bibliography on Anderson including his books, novels, articles, and where reproductions of his work appear. From looking at the bibliography one can see the prodigious output of writings that Anderson produced. It is important to note that these writings were done while he was taking photographs, making prints, and being a father to

\footnotetext{
${ }^{24}$ Terrance Pitts, "Paul Lewis Anderson: A Life in Photography," The Archive 18 (May 1983) 9.

${ }^{25}$ Ibid. Pitts states Anderson was at one side of an unbridgeable crevasse that separated him and Pictorialism from modern art. Where he denounced Modernism as lacking feeling, Pictorialism was similarly denounced by the modernists.

${ }^{26}$ Donna Bender, Paul Anderson: Photographs (Tucson: Center for Creative Photography, 1983).
} 
two children. Though some of the only scholarly material written on Anderson, this journal and book produced by the CCP are now outdated, as both were produced in the early 1980s.

George Eastman House (Eastman House) published an article about Anderson in Image, the journal of the institution, shortly before The Archive in 1979. This article is a general overview with Anderson and does not explore Anderson in the depth that Pitts did in his article. Instead, it serves as a more of a preview for the exhibition Paul Lewis Anderson (1880-1956) that was at Eastman House in 1979. Written by Susan E. Cohen, curator of an exhibition on Anderson, the article provides a biography of Anderson and extolls some of his views on Pictorialism. ${ }^{27}$ For instance, she discusses Anderson's views on landscape photography as being the most capable of transmitting the artist's intuitive responses to the viewer. ${ }^{28}$ It is not meant to be a scholarly examination of Anderson, but instead a showcase of recent acquisitions by Eastman House.

The recent writing on Anderson is focused on other aspects of Anderson and though it is not as in-depth as Pitts' article, they are still valuable additions to the scholarship surrounding Anderson. Christian A. Peterson, then associate curator of photography at the Minneapolis Institute of Arts, writes about Anderson in an article published in the Bulletin of the Detroit Institute of the Arts. Peterson starts the article by situating Anderson in photographic history. According to Peterson, Anderson was part of a second generation of devoted practitioners that continued with Pictorialism until the 1950s. ${ }^{29}$ Peterson does not focus on Anderson so much as

\footnotetext{
${ }^{27}$ Susan E. Cohen, "Recent Acquisitions: Paul Lewis Anderson (1880-1956)", Image 22.2 (June 1979), 15.

${ }^{28}$ Ibid.

${ }^{29}$ Christian A. Peterson, "Paul Lewis Anderson: Photographer of Light," Bulletin of the Detroit Institute of the Arts 84.1 (2010), 17.
} 


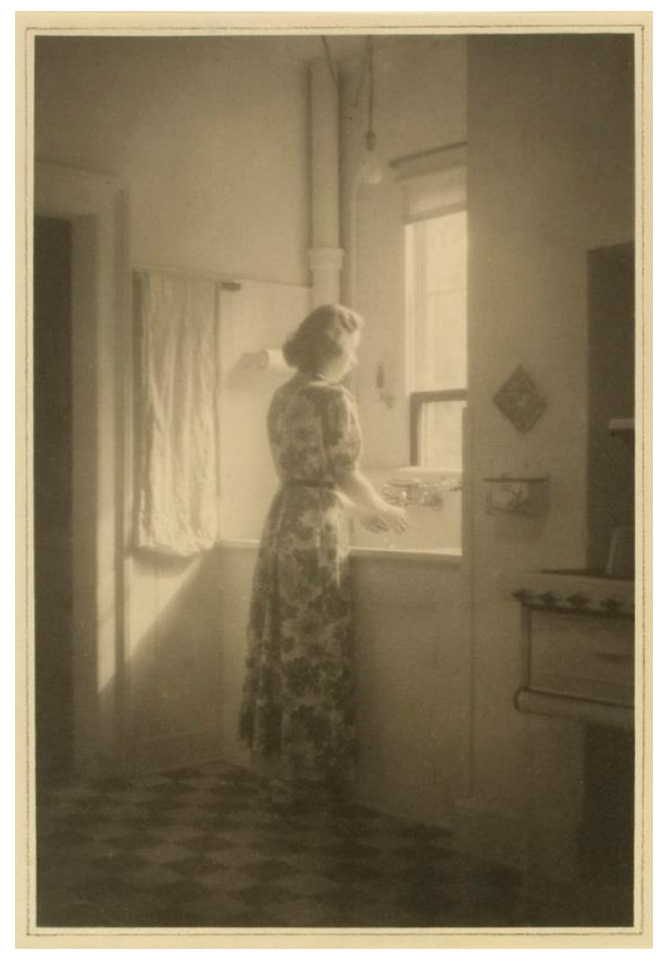

Illustration 5: Sunday Morning, 1944, Palladium print (1976.0315.0322)

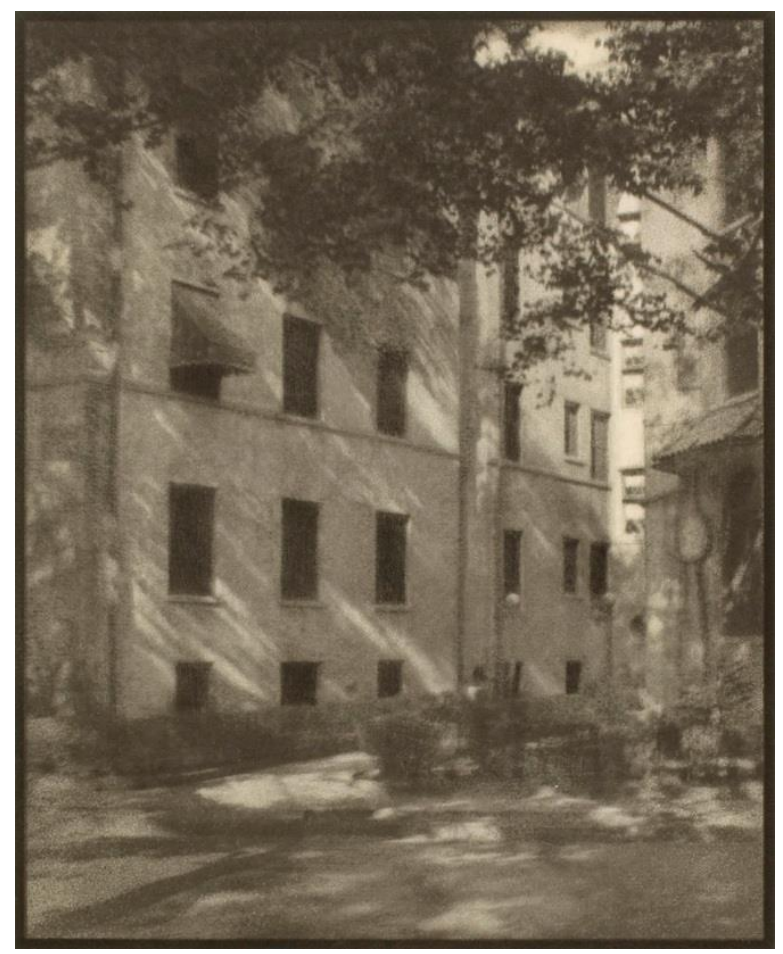

Illustration 6: Shadows and Sun, 1942 Gum bichromate print (1976.0315.0057)

he focuses on a select number of photographs because he is working with the five Anderson photographs in the collection of the Detroit Institute of the Arts. He examines the photographs through their aesthetic and compositional elements, and relates his analysis to Anderson's views on Pictorialism. For instance, when he examines Anderson's Sunday Morning [see illustration 5] he mentions the natural light in the scene that streams through the kitchen window. ${ }^{30}$ This soft light is in contrast to the unlit bare light bulb hanging above the sink. ${ }^{31}$ He ends the article by discussing Anderson's possible links to Modernism, by stating that his photograph Shadows and Sun displays a strong Modernist aesthetic in its composition and focus on structure and form, though it is still in a process favored by the Pictorialists: gum bichromate [see illustration 6]. ${ }^{32}$ Peterson's article is brief, but it contains an examination that is not offered elsewhere; where

\footnotetext{
${ }^{30}$ Eastman House holds six variations of the image Sunday Morning (1976.0315.0321—0326).

${ }^{31}$ Peterson, Paul Lewis Anderson, 20.

32 Ibid, 22.
} 
Pitts offers an examination of Anderson mostly through his writings, Peterson offers an aesthetic look at Anderson's photographs.

While secondary sources on Anderson are lacking, this thesis hopes to contribute to the research by evaluating a number of these sources and bring them together in one document so that this paper can serve as a departure for more study. However, since at least some scholarly critique has been written, it — at the very least — proves that there is a scholarly opportunity to study Anderson that has not been fully explored.

\section{Pictorialism}

Anderson worked within the Pictorial movement for his entire career; however, he is more closely aligned with Pictorialism after 1915, a period that Christian Peterson refers to as the time of the "devoted practitioners." This time period is broad and encompasses many figures and different eras in the late-nineteenth and early-twentieth centuries, and though these are important, I have focused on sources dealing with the later stages of Pictorialism, after 1915.

Discussions of Pictorialism in photographic history are often weighted to its early period, starting in the 1880 s and recording the evolution of the movement until 1915. This was a time dominated by Alfred Stieglitz and his circle, including turbulent debates over the nature of photography. After this period we see a pluralism come to Pictorialism that preserved and lasted for many decades. Pluralism in the sense that we see different levels of amateur, professional, and artistic Pictorialism coexisting and thriving.

Informing my understanding of Anderson's place in Pictorialism are a number of sources about Pictorialism after 1915. For broad strokes of the later decades Christian A. Peterson's After the Photo-Secession: American Pictorial Photography 1910 - 1955 is especially helpful. 
Peterson's aim is to correct the assumption that Pictorialism disappeared or became derivate after $1915 .{ }^{33} \mathrm{He}$ does this through examining the specific salons, photographers, and the eventual decline of Pictorialism. Peterson argues its demise was from being democratized to the point where the movement was only part of the large machine of the institutions which created it. ${ }^{34}$ Peterson mentions Anderson in the text, often by explaining his views or his cantankerous opinions. For instance, Peterson mentions that Anderson decries the use of large prints, preferring smaller and more intimate sizes. ${ }^{35}$ Peterson's book is a valuable addition to the literature surrounding Pictorialism after the Photo-Secession.

The book Pictorialism into Modernism: The Clarence H. White School of Photography is helpful to contextual Anderson's time at The Clarence White School and the burgeoning education of Pictorialists. ${ }^{36}$ Though the book is more about White, his influences, and his philosophy on education, it provides insight into the way that Anderson came to be at the school and the atmosphere in which he taught.

Anderson is mentioned in George Eastman House's publication and exhibition, Truth/Beauty: Pictorialism and the Photograph as Art, 1845-1945. The book and exhibition are about Pictorialism, and Alison Nordström, the curator of the exhibition and contributor to the book, mentions Anderson in the context of his printing techniques and how they shape the responses to the images. ${ }^{37}$ In particular, Nordström mentions a series of prints of Vine in Sunlight, printed in gelatin silver chlorobromide, gelatin silver bromide (that is, gelatin silver paper where silver bromide forms the image, not a mixture of silver chloride and bromide), and

\footnotetext{
${ }^{33}$ Ibid, 9.

${ }^{34}$ Ibid, 151.

${ }^{35} \mathrm{Ibid}, 48$.

${ }^{36}$ Bonnie Yochelson and Kathleen A. Erwin, Pictorialism into Modernism: The Clarence H. White School of Photography, ed. Marianne Fulton (New York: Rizzoli, 1996)

${ }^{37}$ Alison Nordström and Thomas Padon, Truth/Beauty: Pictorialism and the Photograph as Art, 1845-1945 (Vancouver: Vancouver Art Gallery, 2008, 45-46.
} 
gum bichromate. Incidentally, these works were also the most recent prints in the exhibition, dating from 1944.

Finally, a PhD dissertation on the development and institutionalization of the salon aesthetics and systems helped to contextualize Anderson's middle and later era. ${ }^{38}$ The text is thoroughly researched and covers a great deal of information in its more than 600 pages. Michael Griffin, the author, traces the development of the amateur pictorial aesthetic, from its beginnings in the 1880 s and 1890 s through to its codification and widespread adoption in the 1920 s. Griffin's study helps to ground Anderson. Where Pitts paints a picture of Anderson as an increasingly solitary figure, Griffin shows that alienated as Anderson might have been, he was still working while an advanced and large framework of Pictorialist organizations existed.

\section{Photographic Processes}

Anderson used a number of photographic processes in his career, from gum bichromate to manufactured gelatin silver papers such as bromide and chlorobromide. As such, the amount of literature on the processes ranges from plentiful to scarce. Anderson's books and articles provide an ideal resource for examining the photographic processes that he used, because these are the processes he writes about. In Anderson's last book, The Technique of Pictorial Photography, he discusses photographic processes at length. ${ }^{39}$ For instance, when he explains platinum printing, he not only explains the steps to the process, but the type of negative required, the materials needed, making the sensitizing solutions, printing, and finishing techniques with his

\footnotetext{
${ }^{38}$ Michal Griffin, Amateur Photography and Pictorial Aesthetics: Influences of Organizations and Industry on Cultural Production PhD. Diss, University of Pennsylvania, 1987

${ }^{39}$ Paul Lewis Anderson, "Technique of Platinum," The Technique of Pictorial Photography (Philadelphia: Lippincott, 1939), 194-214.
} 
view of the process as one of the easiest techniques to learn. ${ }^{40}$ Also, Anderson includes many diagrams, figures, and formulae that may point to his engineering and scientific backgrounds. His books are especially useful for examining processes that have since faded into obscurity, as he explains these with detail. For instance, he has an entire section on color photography and from a contemporary view his writings provide a valuable summation of early color processes that do not have much other information written about them, such as Hicrography or Three colour gum bichromate ${ }^{41}$ It is also worth noting that Anderson categorically devotes relatively little space to gelatin silver processes. For instance, in The Technique of Pictorial Photography he does not include a single section on that process. This belies the fact that he used gelatin silver papers — especially the chlorobromide emulsion — extensively during his career, and indeed more than a quarter of the Eastman House holdings are gelatin silver prints.

Contemporary texts also inform an understanding of the processes Anderson used. They provide preservation information and contextualize the processes in the history of photography. Especially helpful is Bertrand Lavedrine's book on photographic processes. ${ }^{42}$ Lavedrine concisely covers photographic materials from 1839 to the present and gives the reader information on the uses, fabrication, and conservation of these processes. Also helpful is Sarah Kennel's In the Darkroom: An Illustrated Guide to Photographic Processes before the Digital Age, as this resource provides not only notes on the process, but also illustrations and identification guides. ${ }^{43}$

\footnotetext{
${ }^{40}$ Ibid, 194.

${ }^{41}$ Ibid, 341-363.

${ }^{42}$ Bertrand Lavedrine, Photographs of the Past: Process and Preservation (Los Angeles: Getty Conservation Institute, 2009).

${ }^{43}$ Sarah Kennel, In the Darkroom: An Illustrated Guide to Photographic Processes before the Digital Age (Washington: National Gallery of Art, 2009).
} 
Another useful source are the modern working guides to photographic processes. These manuals are for the advanced photographer or one working in alternative processes. Apart from using modern language, instructions, and descriptions, the manuals often have a section on the history of the process. Also, these books often are an authority on the subject and include information on a variety of subjects related to the process. For instance, Luis Nadeau's History and Practice of Oil and Bromoil provides a history and complete guide to the process, and a bibliography of sources, both historical and contemporary. ${ }^{44}$ Another contemporary text explains modern ways for carbon transfer printing, a method Anderson used fairly frequently. The Bostick \& Sullivan Book of Modern Carbon Printing provides readers with an overview of how to make carbon transfer prints using homemade tissue-because it is no longer manufactured, unlike in Anderson's time when it was manufactured by the Autotype company. ${ }^{45}$

The Image Permanence Institute's Graphics Atlas also provides a valuable resource for information on photographic materials, especially for process identification. ${ }^{46}$ The website offers comparisons of processes and magnification of image areas to aid in learning and identifying processes. The site is updated and new processes are added to make for a more comprehensive resource. By showing how processes progressed through to today, the site not only offers a technical and scientific dissection of photography, but also offers a history of the medium because we can see how photography was used by professionals and the public.

${ }^{44}$ Luis Nadeau, History and Practice of Oil and Bromoil printing (Fredericton, NB: Atelier Luis Nadeau, 1985).

${ }^{45}$ Dick Sullivan, The Bostick \& Sullivan Book of Modern Carbon Printing (Santa Fe: The Bostick \& Sullivan Press, 2007).

46 “Graphics Atlas,” Image Permanence Institute, accessed June 14, 2015, http://www.graphicsatlas.org/ 


\section{Archival Description}

Proper description of objects is vital to create a cohesive record of a collection.

Therefore, using the appropriate cataloging manuals and following key principles was important when crafting the collection guide and cataloguing the Anderson photographs for this thesis.

The George Eastman House Cataloging Manual provided the preferred in-house style for cataloguing. This document is meant to create uniformity between records. With Anderson this become a problem because he used many processes that have subtle variations. For instance, he used gelatin silver chlorobromide paper, which has a subtle difference from other gelatin silver papers as it produced warmer tones and yielded a softer and greyer image. I felt that it was important that these attributes were included into the catalogue records so future users can search for these terms.

When crafting the collection guide I followed the rules for describing archival records to ensure the guide is worded correctly and was approachable for researchers. For this Describing Archives: A Content Standard (DACS) by the Society of American Archivists was applied. ${ }^{47}$ Though I am not crafting a finding aid in the classical sense - where the objects are broken down into box level and item level description is not always used - it is still important to have consistency and have fields state certain information. For example, an optimum DACS field is Administrative/Biographical History. ${ }^{48}$ This is especially useful for discussing Anderson because he is not well known.

\footnotetext{
${ }^{47}$ Society of American Archivists, Describing Archives: A Content Standard (Chicago: SAA, 2013).
}

${ }^{48}$ Ibid, 34. 


\section{Access to Collections}

Access to collections is a common concern in the museum field today. With the rise of digital technologies and the internet, there was been a concerted effort by many institutions to give better access to their collections. Some journal articles have been written, but because of the nature of the internet, often the best sources are online news articles or blog posts from various institutions.

Access is a balance of many different factors. If a collection is going to be online then certain concessions have to be made regarding copyright and access to images of the work. Also, the information must be accurate because the information is no longer just accessible to workers at the museum and researchers, but accessible by the general public. This also means that relations between objects need to be clearly defined so searching is streamlined.

A truly inspiring take on balancing access and taking advantage of the functionality of the internet, instead of its limitations, is the website for the exhibition Object: Photo ${ }^{49}$ Produced by the Museum of Modern Art (MoMA), the website is dedicated to the Thomas Walther Collection: a collection 341 photographs that represent "the innovative vision of the 1920s and '30s, a transformative period of modern photography and the foundation of our photo-based world." ${ }^{50}$ The website includes high-resolution images, guides to the photographic techniques shown in the photographs, and scholarly articles that contextualize the period. It is exhaustive in its scope and detail and users could spend hours browsing through the different sections.

Object:Photo is the result of many people's efforts, time, and money, thus this is something that I could not possibly achieve with the Anderson collection at Eastman House in the time I had to

\footnotetext{
${ }^{49}$ Museum of Modern Art, Object Photo, accessed June 14, 2015, http://www.moma.org/interactives/objectphoto/

${ }^{50}$ Ibid.
} 
complete my project. Instead, this serves as an example of what can be done to make a collection accessible in an interesting way.

Another example that is perhaps less grand in its vision but more of a model for what access to the Paul Lewis Anderson holdings will look like one day is the resources on the Center for Creative Photography (CCP) website. They have a page dedicated to Paul Lewis Anderson and their holdings of his work. ${ }^{51}$ The page gives a brief biography of Anderson and lists the resources they have for him. They include two downloadable documents: a finding aid and a list of photographs. They also have all their holdings of Anderson digitized and accessible. This page provides a good example what other institutions are doing to make their collections available online.

Recently, the Metropolitan Museum of Art in New York City made their collection available online. This follows a trend of museums trying to create access by using blogs and specific websites to attract the public. ${ }^{52}$ The Imperial War Museum in London, United Kingdom has also made a similar move. They made thousands of videos, sound recordings, and images available online for the public to access while the museum was closed for renovations. ${ }^{53}$ Lynsey Martenstyn explains in an article for The Guardian that having items accessible online is good for a number of reasons, she states:

And the benefits go beyond access. A digitized archive collection is an educational tool tooteachers and academics can access our collections with ease to enrich lessons or their research. It also enhances the audience experience, with visitors able to access items of their choice, before or after their stay, before sharing their favorite artifacts online, by email or over social media with the help of a tweet. ${ }^{54}$

${ }^{51}$ Center for Creative Photography, Paul Lewis Anderson, accessed June 14, 2015, http://www.creativephotography.org/artists/paul-l-anderson

${ }^{52}$ Ken Johnson, "No Detail Goes Unnoticed When Art Is a Click Away," The New York Times January 29, 2015.

${ }^{53}$ Lynsey Martenstyn "Digital archives: making museum collections available to everyone," The Guardian May 3, 2013.

${ }^{54}$ Ibid. 
From this article, and the example websites provided, it is clear that access through the internet is starting to be looked at in a different way. Since this is an emerging field, news articles and digital sources may be the best sources for information, particularly because by the time a scholarly book is published the information may be outdated, while with digital sources they can be updated as information becomes available. 


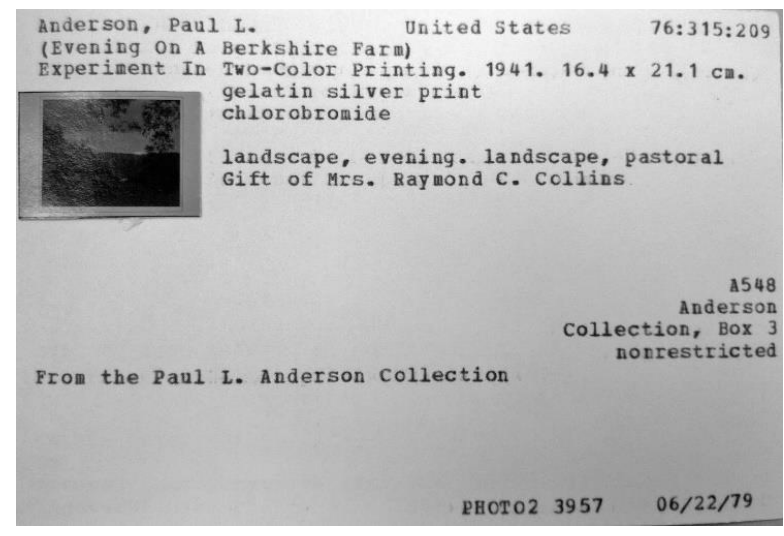

Illustration 8: Example of cataloging card

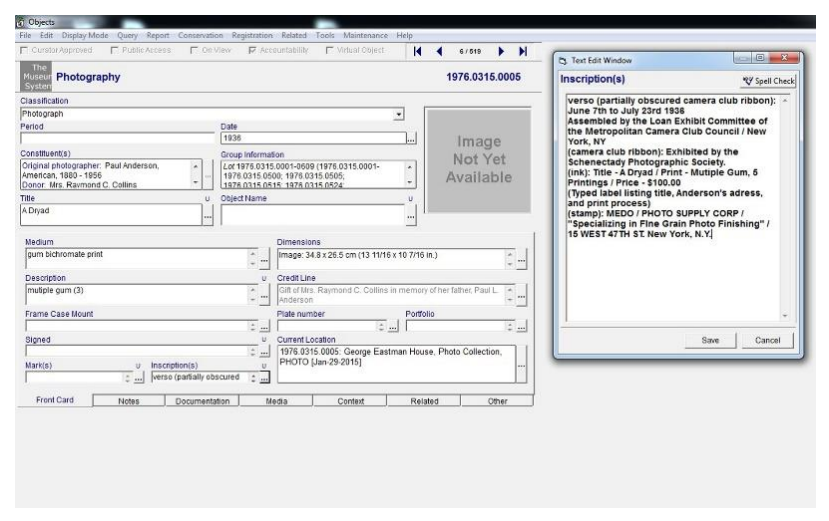

Illustration 7: Example of TMS cataloguing screen

\section{PART III: CATALOGUING THE ANDERSON PHOTOGRAPHS}

Expanding and facilitating access to the Paul Lewis Anderson photographs involved cataloguing each object and inputting the information into the appropriate fields in The Museum System (TMS), the collections management system used by George Eastman House. This task involved many different ways of thinking about the objects. This section discusses the process I used to catalogue the Anderson photographs, highlights of what I learned through the process, and how what I learned informed my understanding of Anderson. I also highlight some of the challenges that I encountered along the way.

Before I started cataloguing the objects there was a minimal amount of information entered into TMS. The only objects that had any amount of data entered in TMS were objects that appeared in exhibitions, which was less than 100 out of the 494 objects. Even with this, the information in the fields did not necessarily correspond to the current standards established by the Photography Collection for cataloguing. For instance, some objects that had titles were given descriptive or incorrect titles because the cataloguer may not have known that the title was on the verso of the mount. These records were updated accordingly. Also, the objects were not broken out past the lot level, meaning that although accession numbers were assigned to each of the 
objects individual records had not been made for each object and indeed a large majority of the objects were represented by only one record (e.g. 1976.0315.0001-0323). In preparation for cataloguing the lot was broken out into individual records so that when a user searched for Paul Lewis Anderson the records returned represented individually each objects related to him.

Though the objects had little information in the current collection management system and were not broken out past the lot level, they were catalogued using previous means. In 1977, they were catalogued using a computer that outputted the data onto cataloguing cards. This system was high-tech for its day and included item-level information such as title, date, medium, image dimensions and subject attributes (terms that can be used in keyword searching, e.g. flowers, portrait, or airplane). ${ }^{55}$ Also, a thumbnail photograph was affixed to the card. These were placed in a card catalogue, separated by photographer, allowing access for on-site researchers and staff. However, this system of searching and retrieval was rendered obsolete when computer-based databases that rely purely on a graphic user interface were introduced, the most current iteration being TMS.

\footnotetext{
${ }^{55}$ For an in-depth discussion of the way Eastman House used computers, see: Image: Journal of Photography and Motion Pictures of the International Museum of Photography at George Eastman House 21.4 (December 1978).
} 

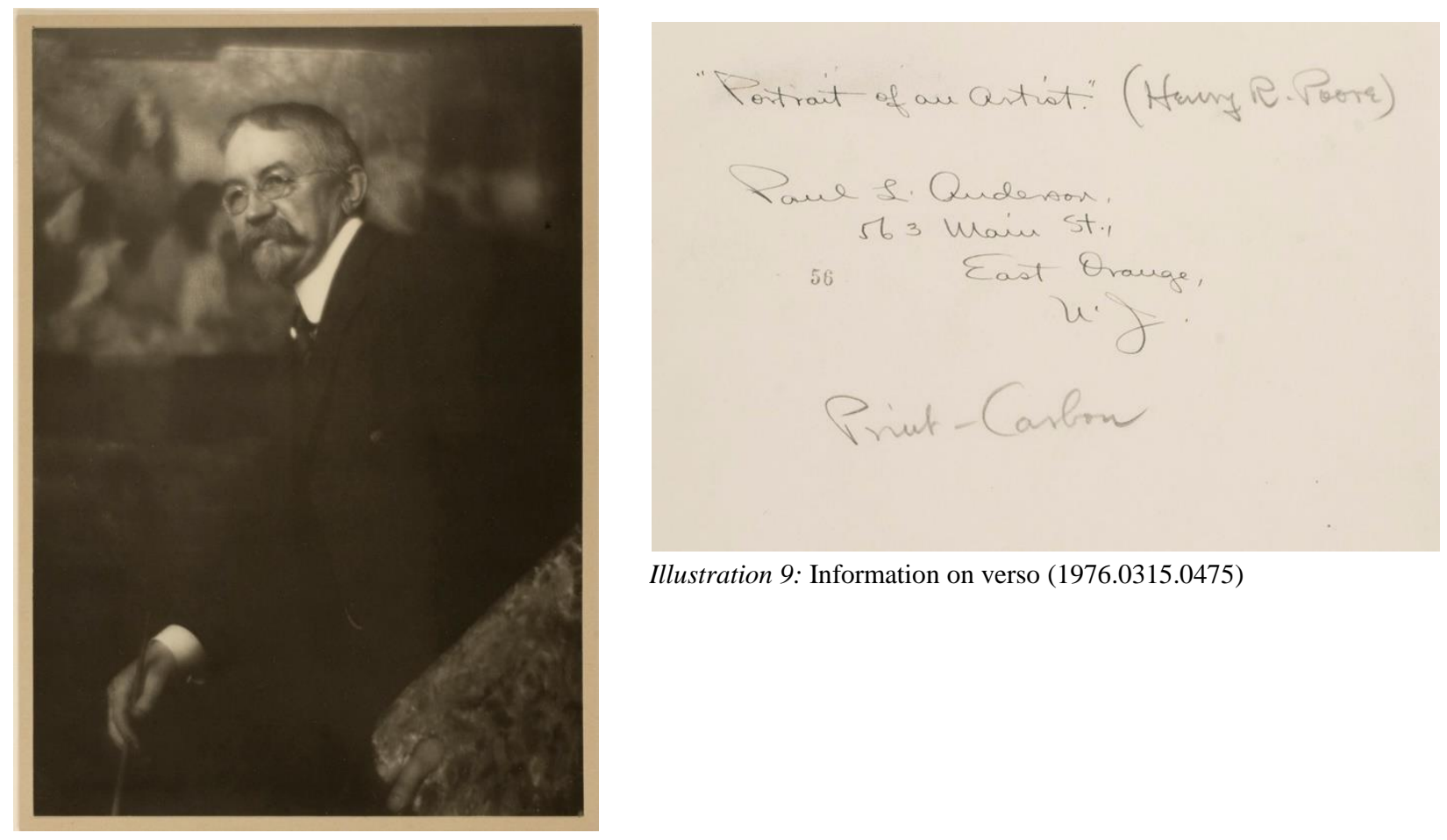

Illustration 9: Information on verso (1976.0315.0475)

Illustration 10: Portrait of an Artist (Henry R.

Poore), 1913, Carbon print (1976.0315.0475)

For the purposes of time and ease of cataloguing, I started by using these cards to enter the basic information about the objects. This means I could go through the records faster than if I catalogued all fields directly from the objects and this also meant that object handling was reduced, increasing preservation. With the cards, I entered the data for the title, date, medium, image dimensions, and subject attributes. The only field that I found to be incomplete on the cards was the dimensions field; only the image dimensions were listed and this does not conform to current standards, where image is usually followed by another measurement for the mount or the overall dimension. Overall, the catalogue cards allowed for better time management and meant that I could more quickly enter accumulated data. Rather than accessing the photographs during only the open hours of Gannett Foundation Study Center, I could take the cards and enter the data on weekends or evenings in a computer lab at the museum to better suit my schedule. 


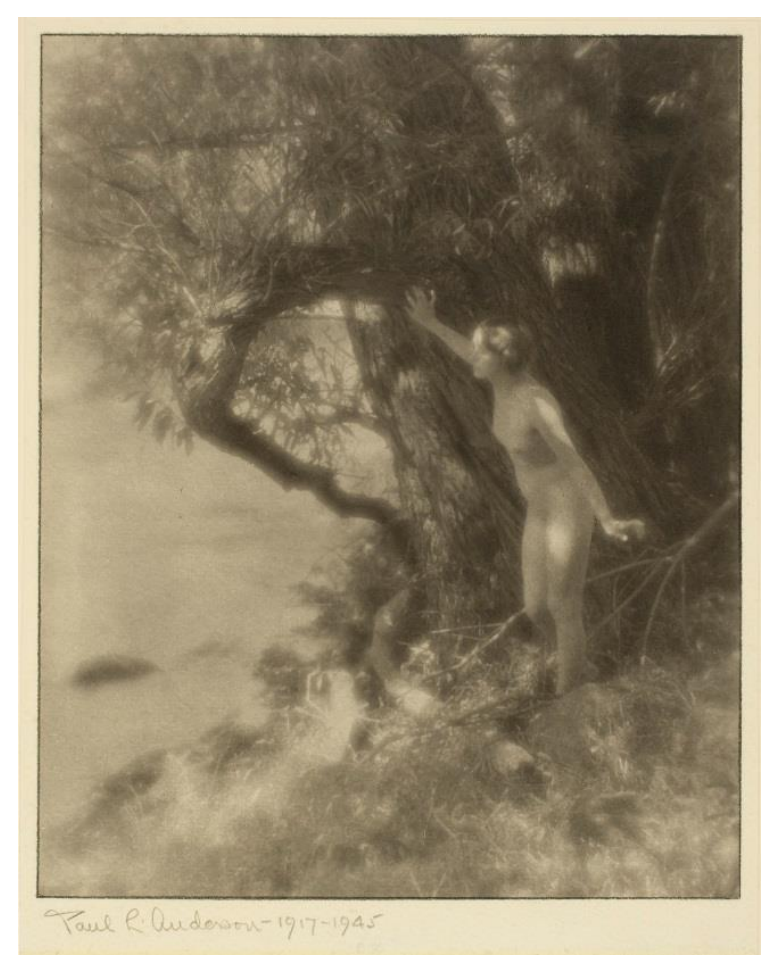

Illustration 11: A Dryad, 1917, Palladium print

(1976.0315.0006)

Anderson was exacting in his photographic technique but also in the way he labeled and identified prints. Almost all of the prints are titled in easy to read titles (in uppercase, roman, and typed words) on the versos of the mount. He frequently gave his photographs pictorial titles to match the aesthetic and subject matter. For instance, a photograph depicting a nude women by a body of water is titled "A Dryad" after the wood nymph in Greek mythology [see illustration 11]. Others are titled after the location in which they were taken, for instance, photographs taken around the New York Public Library are titled accordingly. Portraits are usually titled with the name of the subject (e.g. Henry R. Poore), but in some cases are given a more illustrative title (e.g. another portrait of Poore is titled Portrait of an Artist [see illustration 9 and 10]). A very small amount of works are untitled, that is no title is written or typed on the work, and these works were assigned descriptive titles to aid in retrieval. 
Anderson also made every effort to state the medium of the print on the verso. These are either written in pencil, separated by dashes from the title or-more commonly—typed on a label and affixed to the verso. Anderson also included if the photograph was made with two or more processes or included coatings. For example, frequently with his gum bichromate prints he used more than one pigment and coated the paper more than one time to increase contrast. A minority of Anderson's prints are of unidentified processes. These are mostly confined to a single album that Anderson produced in 1909 - the year he began photography in earnest.

These unidentified prints were identified with the help of Alice Carver-Kubik, Photographic Research Scientist at Image Permanence Institute. Using a methodical approach for looking and examining the prints through magnification, subject matter, and date, we identified the process for a number of his prints. We also came to indeterminate conclusions about small number of others. For 14 photographs we used X-Ray Fluorescence Spectroscopy (XRF) to determine the chemical composition of the final prints. For the majority of prints we tested we were able to identify the processes ${ }^{56}$ however for two prints we were only able to hypothesize that the prints were gum bichromate over platinum prints. ${ }^{57}$

Anderson also dated the majority of his prints. This appears on the recto, under the image area and next to his signature. Curiously, Anderson sometimes gave his prints a date range of a number of years. For instance, the photograph mentioned above, A Dryad, is given a range of 1910 to 1945 . This is a sizeable range and the two dates can be thought of in two different ways. One, Anderson did not date the print until years after he made it and was unable to remember the exact year and instead he created a range that spans his career. Or, the dash between the years is

\footnotetext{
${ }^{56}$ We identified the following prints: (1976.0315.0039,0054,0095,0166,0217,0221,0224,0229,0231,0235,0239,0487)

${ }^{57}$ We can to indeterminate conclusions about the prints: 1976.0315 .0081 and 1976.0315 .0181
} 


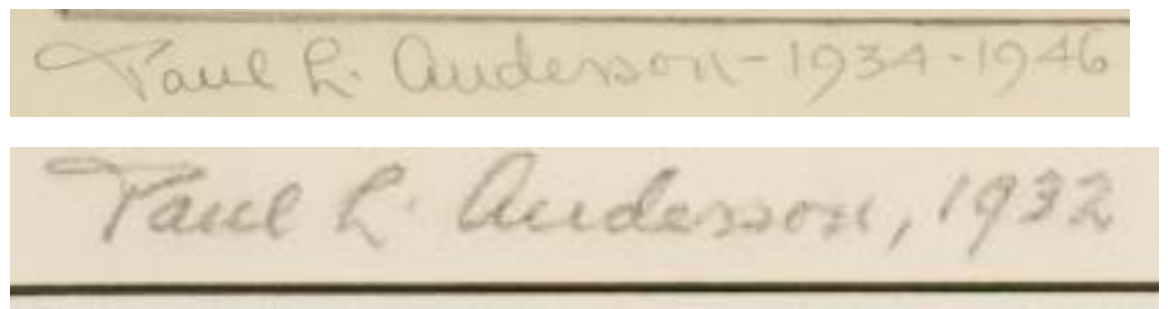

Illustration 12: Both are the same image yet show different dates. Top: 1976.0315.0126; bottom: 1976.0315.0127.

not meant to signify a range, but instead a negative and print date. Further proof of this can be seen in the inscriptions on the multiple prints of the work Paradise Pond [See illustration 12]. ${ }^{58}$ Some list 1932 or 1933 as the date, but others have a range of 1934 to 1946 . Since these are all from the same negative, we can deduce that the photograph was taken in 1932 and the subsequent dates are ranges for when a specific print was created. In short, Anderson's use of ranges is confusing; does he indeed mean a range, or is it a negative and print date? For the purposes of cataloguing I have retained the ranges, but have moved them to the historical date field in TMS. For instance, for Paradise Pond, I have made all the dates read as only 1932, but have kept the ranges because they are still relevant information for future researchers.

The catalogue cards also listed a number of subject attributes related to an image. For instance, a still life of a rose may have "still life // rose" as an attribute. I tried to have a minimum of three related subject attributes for each image to aid in searching. For some images this was harder than it was for others, for instance, portraiture posed a challenge if Anderson photographed an unnamed subject, but overall I drew on the terms included on the cataloguing cards and the experience of past cataloguers.

Entering the data on the cards coincided with the images being digitized by Barbara Galasso, head of the Photographic Services Department at Eastman House. She photographed the

\footnotetext{
${ }^{58}$ Image is alternately titled Paradise Road (1976.0315.0127), but all versions are presumably from the exact same negative.
} 
front and back of Anderson's photographs, edited the files, and outputted the files to a jpeg format that I could access. The image files aided in my ability to transcribe inscriptions from the objects, again, limiting my need to handle the objects directly and allowing me to work outside of the hours of the study center. In the future they will also be input into TMS to serve as image reproductions of the objects, assisting the staff in identifying the photographs and allowing researchers to better define which objects they wish to view

For the inscriptions, Anderson wrote on the front and back of most of his photographs. I transcribed and entered this information into the appropriate field in TMS. Anderson frequently signed and dated the front his photographs, with the verso showing information about the medium, title, and Anderson's address. This is interspersed with the occasional note on the specific technique he used for this print, a message to a friend, or a note that states the price or that the work is not for sale. Anderson seemed to keep the writing to the essential facts about an image. He always wrote in pencil and always in a legible hand. Overall, transcribing the inscriptions made his technical information searchable, and will aid staff members and researchers.

Overall, I approached the cataloguing of the Anderson photographs by using a combination of old and new technologies. Starting with the cataloguing cards, then using digitized versions of the photographs to transcribe inscriptions, and finally double checking information and taking overall dimension measurements from the objects. This allowed me to efficiently and accurately catalog the photographs. This also allowed for more chances to recheck my work, as I went over each record more than one time throughout the process.

Having viewed 492 objects by Paul Lewis Anderson, it was impossible for me to not gain a better understanding of his work. Since there is relatively little scholarly material written about 
Paul Lewis Anderson, I relied on the objects to inform my understanding of him and his artistic practice. While I worked to document each object in TMS, I found the process also provided for a great learning opportunity. It was not only a chance to learn about correct nomenclature and standards within the museum field, but it was also a chance to discover an artist firsthand by studying the objects that he made. I learned about his photographic processes, the life of this artist, and the conditions of his time all by studying the objects and compiling research. My work with the collection opened up new points of departure for studying him. These new departures will be discussed more in-depth in my conclusion, but for now I will discuss what I learned from looking at the Anderson material.

Certain aspects in the work of Anderson changed over time. The way he inscribed prints and versos started rather simply and over time evolved to the use of applied labels. Additionally, Anderson always signed his prints, but his signature changed over time. ${ }^{59}$ In his early years, he used a simplified signature that was often placed in the image area. Around 1909, he frequently printed simply "ANDERSON" in pencil and then the date. On a few prints, he used a stylized colophon, in a similar vein as Edward Steichen and Alfred Stieglitz, and this consists of "PLA" in a stylized rendering [see Collection Guide: Section 4: Characteristic Inscriptions, Figure 13]. Around 1915 he settled on the signature that he used, with a few exceptions, for the rest of his career. ${ }^{60}$ This consists of his full name, "Paul Lewis Anderson," handwritten in neat cursive writing followed by a dash, or sometimes a comma, and the date. This is written on the bottom of the print and it seems that Anderson trimmed his prints to the image area, but left a margin at the bottom to sign and date the print.

\footnotetext{
${ }^{59}$ See Collection Guide: Section 4: Characteristic Inscriptions for examples of his signatures.

${ }^{60}$ Curiously in 1944 he returned to using a colophon for on a few prints. See: Collection Guide: Section 4: Characteristic Inscriptions
} 
As mentioned above, the verso of his works would typically include the title, medium and often his address. A verso that shows all of these aspects and deserves mention because of the sheer amount of information contained on it is for the print titled Paradise Pond: Smith College [see illustration 13], a photograph Anderson took on the grounds of Smith College and for which multiple variant prints exists, including a loose mounted print and mounted print in a two volume album. The verso of this particular print displays camera club ribbons, the typed labels that are characteristic of Anderson's work, and a surprisingly detailed note about the equipment and process that he used. ${ }^{61}$

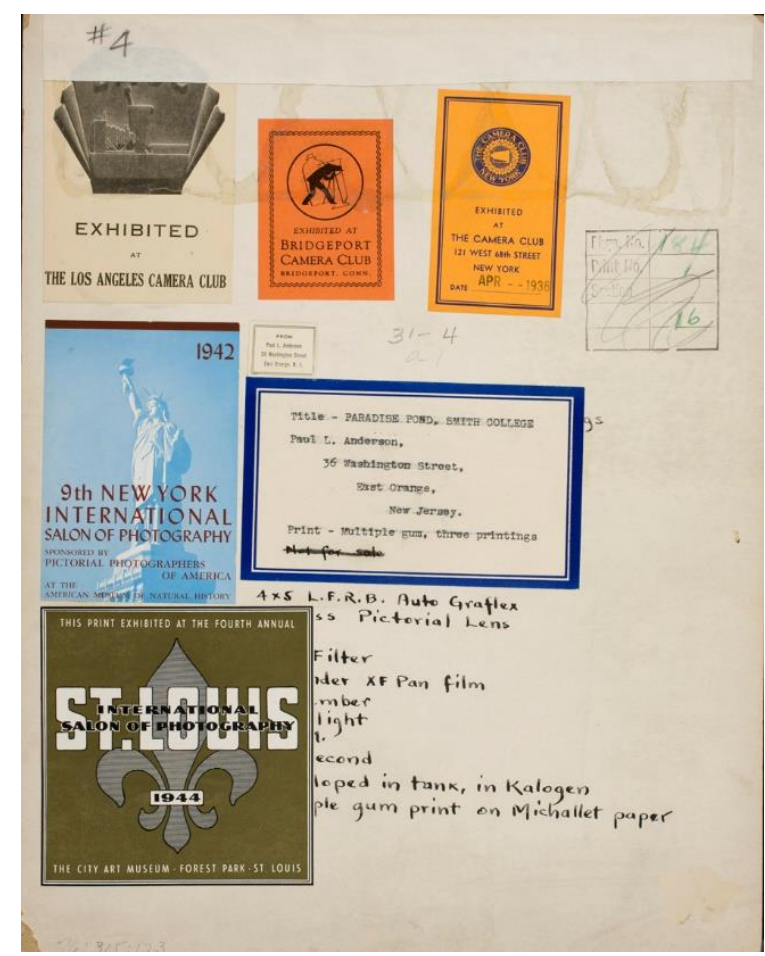

Illustration 13: Verso of 1976.0315.0123, showing many different types of inscriptions

The five camera club and salon ribbons adhered to the verso of this print show a crosssection of the United States, with ribbons appearing from venues across the country: The Los

\footnotetext{
${ }^{61}$ The verso technical inscription reads: 4x5 L.F.R.B. Auto Graflex / [obscured] ss Pictorial Lens / Filter / [obscured] nder XF Pan Film / [obscured] mber / light / [obscured] econd / [obscured] loped in tank, in Kalogen / [obscured] ple gum print on Michallet paper
} 
Angeles Camera Club, The Bridgeport Camera Club, The New York Camera Club, The Pictorial Photographers of America (the $9^{\text {th }}$ International Salon of Photography in New York City), and The St. Louis International Salon of Photography. These ribbons are dated in the 1930s and 40s, which proves that not only did these salons competitions continue into the 1940s, they also continued during wartime. The left side of the verso contains a stamp that lists package number and print number, information most likely added by a camera club for in-house tracking.

The verso also contains two different address labels for Anderson; one is the postage stamp sized one that appears infrequently on his prints (usually along with a handwritten note listing the title and process), and the other address label is Anderson's more common blue bordered typed label. It also lists more about the photographic process than usual by stating that it is a gum print with three printings (i.e. three exposures where one coat of pigmented gum arabic was applied with each exposure). Additionally, the bottom line reads "print is not for sale" but it has been crossed out. While monetary value is not frequently listed on Anderson's work, this proves that he thought about selling his work - though it remains unknown if he made any substantial money off his sales.

The last interesting aspect of this verso is the technical information. This is partially obscured by a camera club ribbon, but it is still legible. Anderson lists the camera he used, the lens, the type of filter, the film used, the month, the light, the exposure time, the type of developer used, the print process, and the type of paper that he used. This is not something that Anderson usually lists so it is interesting to see that he recorded all of the information related to the print and negative.

Anderson also changed the way that he inscribed the versos over time. At their most basic, the prints are simply marked with the title and medium. This is characteristic of his early 


\section{Title - WHAT DO THE CRITICS SAY?}

PauI L. Anderson

36 Washington Street

\section{Last Orange}

New Jersey

Print - Chlorobromide

Illustration 14: Applied Label on verso of 1976.0315.0457

work (from 1909 to approximately 1915), and these prints were frequently not mounted on board or tipped in to paper. Moving up in terms of information, sometimes this handwritten inscription was supplemented by a postage stamp sized label that has Anderson's studio address typed on it and affixed to the verso. On other prints, he writes out the title, his address and the process on the verso. Finally, the most common information on the verso is a typed label, outlined with a blue or red border, which lists the title of the photograph in capital letters, Anderson's studio address, and the process of the photograph [see illustration 14]. The inscriptions on the versos show that Anderson increasingly valued proper identification on his prints by giving them typed labels that listed the pertinent information. This could also be out of necessity because Anderson was a regular contributor to photographic salons and camera club exhibitions throughout his career, so he needed the titles and process to be clearly identified. This also fulfills the dualism of the salon world that Michal Griffin discussed (mentioned in my introduction); Anderson was giving these photographs aestheticized titles, while also going into great detail about the process he used. This 
would have appealed to salonists that not only recognized the pictorial aesthetic, but also could be impressed by Anderson's technical ability.

With the inscriptions, we can also trace an outline of his working life. Anderson used three addresses during his career, all of which are in New Jersey. The one that is in use the longest was the address for his studio at 36 Washington St. in East Orange, which he used from the 1910 s to the 1930 s. For a brief period during this time he was at another address, 563 Main Street in East Orange (prints with this address are from approximately 1910 to 1915), and finally he was based out of Hillside Avenue in Short Hills, New Jersey from the 1940s until his death. All three of these areas were prosperous when Anderson worked out of them and reflect his upper middle-class background. Furthermore, this means that he had a studio or place of business out of which he presumably worked and made money.

Another aspect of Anderson's photographs and something that is in need of further study is the variety of camera club ribbons that decorate the versos. From the ribbons, it is clear that Anderson submitted work to a number of camera clubs and salons in North America and Europe. He submitted work to some famous clubs, like the Camera Club of New York. Also, to clubs closer to home, including the East Orange Camera Club. Also, some international clubs like the Shropshire Photographic Society in England. These ribbons are in the form of applied labels. Most are decorative in design and proudly list the event, camera club, and dates that the work was on exhibition. Some show landmarks unique to the city such as the Statue of Liberty New York or the Terminal Tower for the Cleveland Camera Club.

Cataloguing and critically looking at the Anderson material has expanded my understanding of Paul Lewis Anderson as a Pictorialist photographer. His work has been collected by two major institutions, George Eastman House and the Center for Creative 
Photography, but many of the people that he competed against may have slid into obscurity. As an extant example, his body of work provides research potential for many subjects related to Anderson. Cataloguing these works was the first step towards making the material available for researchers.

This section has expounded on the process and methodology that I used to approach the Anderson material. Using a combination of object-based and digital cataloguing methods, and by taking advantage of what information had already been accumulated, I have expanded the information for the records in TMS. This has opened up the institutional knowledge of the Anderson collection, as staff members are now able to find specific Anderson photographs. This will in turn branch out to researchers and those interested in Anderson because staff members will be more aware of the museum's Anderson holdings. 


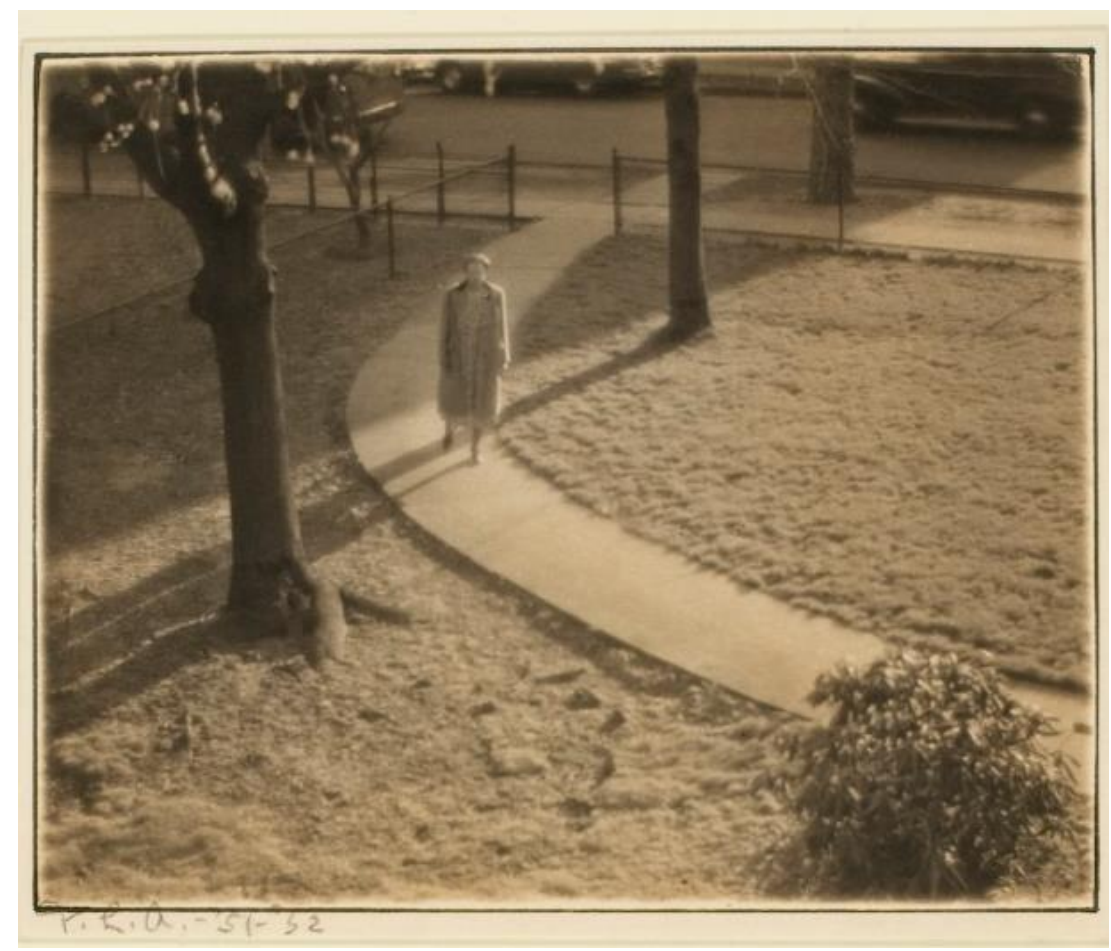

Illustration 15: From my Window, 1951, Palladium print (1976.0315.0017)

\section{PART IV: CONCLUSION}

When Paul Lewis Anderson died in 1956, at the age of 75, his obituary in The New York Times stated that he was an author of many photo books. ${ }^{62}$ It did not mention his ideas on Pictorialism, the large photograph collection that he left behind, or his experimentation with photographic processes. Indeed, after his death he faded into relative obscurity — save for the acquisition of his work by large institutions (most notably George Eastman House and CCP) and the occasional inclusion of his work in exhibitions. It has been the endeavor of this thesis to expand the access and awareness of the Anderson photographs at George Eastman House. This was accomplished by creating a collection guide and fully cataloguing the records in TMS. Both of these resources will be useful for increasing awareness to Anderson's work within the museum and photo history communities both in print as a bound accessible document and online

\footnotetext{
${ }^{62}$ Obituaries, The New York Times, September 17, 1956.
} 
as a searchable document or webpage. This conclusion discusses what was learned with this project, ways to continue to increase access to the Anderson material further, and why the material is important to Eastman House. With this thesis and the accompanying collection guide the work of Paul Lewis Anderson will become a beneficial resource for new generations of scholars, curators, and researchers.

Expanding access creates opportunities for learning and discovery of new material, especially when material is put online, greatly increasing the amount of people that can see it. We live in an age where, by and large, the first steps to researching is using a search engine and indeed, unless one has a specific idea in mind, knows where to look, or knows who to contact, online searching is the typical place to start. Also, having material online does not put physical constraints (e.g. location and time of day) on when a researcher can access the works. Creating online access streamlines research and, with an increasingly technology reliant society, is the future of research. Online access could greatly increase the awareness of Anderson. To make sure that this is accomplished the Anderson material must not be forgotten, and it must be included in future online projects.

Moving Anderson's work into the twenty-first century will involve making it accessible online. In publishing this thesis, the collection will be posted online for access and download in a searchable portable document file (PDF). ${ }^{63}$ This could be taken further by having the Anderson object records online, searchable, and with high resolution images. The Eastman House website is currently undergoing an overhaul with the hope to have the collection online and searchable in two years.

\footnotetext{
${ }^{63}$ This is facilitated by the Ryerson Digital Commons where all current theses are available.
} 
Anderson was not only a photographer, but also a writer and educator, and he worked in the Pictorialist genre for his entire career. This project has allowed me to look at a body of work - a representation of his entire career, from his earliest to his last work. In so doing, I have an understanding of and his community from the photographs, which is in part out of necessity because of the lack of secondary material written about Anderson. One only has to look at the versos of some of his prints to get a sense of this community. Anderson's prints are decorated with the ribbons from tens of camera clubs around the United States, and these exhibitions and salons continue in the country until Anderson takes his last picture in 1953. The Pictorialist aesthetic continued well into the 1940s in many circles around the United States and Europe. It is an oversimplification to state that Modernism took hold of photographers and none looked back. Instead, we see both, Pictorialism and Modernism continue and be popular with different groups and schools of photography. Especially with the Anderson photographs we see this continuation of Pictorialism that lasts his entire career.

The Anderson material is untapped potential that could and should be used by Eastman House and other institutions. With Anderson we have a gateway into a specific time and era in photography. By studying the era through his photographs it can be a potential topic for historians to learn about not only Anderson, but his contemporaries and this pictorial era. From a scientific standpoint his materials can aid in the learning about processes and the different materials that were in use at this time. Finally, from a curatorial standpoint his photographs offer another way to view Anderson and explore ideas, themes, or processes.

By looking at the subject matter of his photographs historians will be able to better understand the era that he worked in. This is significant because with only a few sources written on this era, the Anderson photographs could support and illustrate research and provide a solid 
ground for historicizing this era. The research potential with these photographs lies in its diversity, or at least diversity within a specific style-Pictorialism. Even though his photography uses the aesthetic of Pictorialism, often in soft focus, they can still be viewed as records of a specific times and place. ${ }^{64}$ His cityscapes are particularly important and this could be another area for study. Also, one could look at his portraits through the lens of the personalities that he photographed, or if Anderson approached portraiture with different ideas. His images certainly portray a sense of what middle class life was like in that time and this is something that could make for an interesting point of departure. This type of study would indeed be relevant seeing as it would greatly add to the material on Anderson and material on the later decades of Pictorialism. From a non-photo historical standpoint his pictures can be viewed through their subject matter and can be compared with notions of the middle class in early twentieth-century America and how Anderson fills certain roles that would have been expected of him as a middle class man and a member of the American bourgeois.

There is also scientific research potential that could examine Anderson's techniques and the processes he used. The photographs offer chances to study photographic materials by directly comparing prints of the same negative in different processes. This is significant because one can see how specific areas change from process to process, for example how the shadows and highlights differ in processes, and learn what is different from one process to another. Also, because of the number of prints with unidentified processes and the trouble that was encountered positively identifying them, examining these prints and learning if Anderson did anything specifically different with them could be another way to scientifically examine these prints.

\footnotetext{
${ }^{64}$ That is, the image forms are rendered in a blurry way to accentuate the give, among other aspects, smooth differentiation between tones.
} 
Finally, another opportunity for access is created by having this material accessible for exhibition. From a curatorial standpoint the photographs offer a plethora of materials, subjects, and points of departure for exhibition of Anderson as one who carries on the ideals of Pictorialism well into the 1940s. His work could be in a monographic form (a retrospective of sorts) or shown with other Pictorialists. For a more technical exhibition, a show could explore the processes and techniques that he used. Along with the images, the versos that list the technical information could also be shown. Displaying his photographs would not only take advantage of access created by this thesis, but it would also expand access even further because now the general public can see an exhibition of Anderson's work. Beyond having physical exhibitions, there could be efforts made to increase the public knowledge of Anderson. This could be in the form of blog posts, having his images on photo blog websites like Tumblr, and having online curated, exhibitions. ${ }^{65}$

By facilitating access to the Anderson materials, this thesis has provided a path for future researchers and scholars to build upon the information that I have found and published. As a collection steeped in educational value, the Anderson materials are now rife with opportunities for curatorial and scientific inquiry. These opportunities will shed light on an aspect of Pictorialism that is frequently over looked and is in need of more attention. For George Eastman House, the Paul Lewis Anderson materials provide a multitude of ways to showcase their collections and opportunities for scholarship.

65 These aspects are reliant on copyright. This is discussed more in the collection guide, but in short, the copyright held in his works is managed by Anderson's daughter, Ruth Collins of Short Hills, New Jersey. 


\section{APPENDIX: COLLECITON GUIDE TO THE PAUL LEWIS ANDERSON PHOTOGARPHS}

\section{AT GEORGE EASTMAN HOUSE}

\section{Section 1: Vital Information}

Accession Numbers: $1977.0315 .0001-0487$

Name of Repository: George Eastman House, International Museum of Photography and Film; Department of Photography

Title: The Paul Lewis Anderson Photographs

Date: Earliest 1896, most from 1909 to 1953

Extent: 22 Solander cases, labeled according to process

Name of Creator: Paul Lewis Anderson (American, 1880-1956); also known as Paul L. Anderson, Paul Anderson, Anderson, or P.L.A.

Biographical History: Paul Lewis Anderson was an American photographer who worked in the Pictorialist aesthetic from 1909 until 1953. He trained as an electrical engineer early in the twentieth century, but after being enchanted by the pages of Camera Notes, a publication spearheaded by Alfred Stieglitz, he decided to become a photographer. Out of his New Jersey Studio, he photographed extensively. He worked with such varied subjects as nudes, portraits, still lives, studies of nature, landscapes, and seascapes. Anderson wrote extensively throughout his career about Pictorial photography. He authored books and many articles that appeared in popular magazines at the time. Known for his conservative stance and his adherence to Pictorialism, Anderson also wrote editorials and attacked the modernist aesthetic of Edward Weston and his contemporaries as "vulgar." A constant experimenter, he used a number of processes in his career, which run the gamut from obscure to common place. Other than a short hiatus from photography taken between 1927 and 1933, Anderson exhibited his photographs in salons and at camera clubs around the United States and Europe. He stopped photographing in the early 1950s and died, from illness, on September 16, 1956 in Short Hills, New Jersey.

Scope and Content: 492 photographic prints (either loose or mounted on board); 52 of the 492 photographs are contained in 3 albums.

System of Arrangement: Photographs are arranged by process (e.g. Platinum Case A, Photogravure). Some are broken down further by subject within a process (e.g. Chlorobromide Cityscape, Landscape, Seascapes). Others are grouped together in boxes because they are derived from the same negative, but have been printed using different processes (e.g. same image two processes same image three process). See Section 2. Box lists for more information.

Conditions Governing Access: Access is facilitated through the Gannett Foundation Study Center at George Eastman House, by appointment only. Business hours are Tuesday through Friday, 10:00 am to 4 pm. Contact the Collection Manager (photostudycenter@geh.org) to book an appointment.

Physical Access: Original photographs are housed on-site in the Photography Collection vault. Access is by appointment only. Please indicate the boxes you would like to view when you communicate with the Collection Manager. Photographs are in varying physical conditions, but 
most are in an overall good condition because they are mounted to board. All photographs are housed in polyester sleeves or window matted.

Intellectual Access: Searching can be accomplished in two ways: 1) this guide can function as a search tool because it includes box lists that include all of the photographs; 2) On-site researchers can request to search using The Museum System (TMS), which is useful if one is looking for a specific process or title.

Conditions governing Reproduction and Use: Digital copies of photographs are available. Photographs are protected under copyright. Please consult with appropriate staff members if you desire copies of specific photographs.

Languages: All written information (titles, dates, names, and inscriptions) is in English.

Custodial History: Upon Anderson's death the photographs became the property of his daughter, Ruth A. Collins of Short Hills, New Jersey. In 1976, Collins contacted George Eastman House to offer to donate the collection (including photographs by, of, and collected by Paul Lewis Anderson) in the form of an unconditional gift. The gift was finalized in late 1976, with Mrs. Collins credited as Mrs. Raymond C. Collins.

Related Archival Materials: As part of the donation a selection of Anderson's darkroom notes were also given to Eastman House. These materials are housed in The Richard and Ronay Menschel Library (see Paul Anderson Collection; AR 2015047 Box 41). You may contact the Library at library@geh.org.

Publication Note: See Section 5: Selected Paul Lewis Anderson Bibliography. 


\section{Section 2: Box Lists \\ PAUL LEWIS ANDERSON}

ANDERSON ALBUM, 1910

1976.0315.0217: Miss Brita Dybergh, 1910, platinum print

1976.0315.0218: Women sitting on chair against curtain and screen, ca. 1909, platinum print

1976.0315.0219: Mrs. Frank Mitchell, 1910, platinum print

1976.0315.0220: Woman touching flowers in vase, 1909, platinum print

1976.0315.0221: Mary Greene Anderson and Edward Jennings, 1910, platinum print

1976.0315.0222: Mary Greene Anderson sitting on day bed, 1910, platinum print

1976.0315.0223: Young woman outside in a large courtyard, ca. 1909, unidentified process

1976.0315.0224: Gertrude Gordon, ca. 1909, carbon print

1976.0315.0225: Woman with shawl over her head and holding fan, 1910, unidentified process

1976.0315.0226: A woman wrapped in a blanket, holding cat, 1910, unidentified process

1976.0315.0227: Dr. Frank Mitchell, ca. 1909, gum bichromate over platinum print

1976.0315.0228: Little girl sitting on pillow with a bow in her hair, ca. 1909, platinum print

1976.0315.0229: Nude boy by stream, 1909, platinum print

1976.0315.0230: Mr. Frank Mitchell, 1910, unidentified process

1976.0315.0231: Edward Green, Jr., 1910, gum platinum print

1976.0315.0232: Streetscape, 1910, platinum print

1976.0315.0233: Old woman sitting in rocking chair, ca. 1909, platinum print

1976.0315.0234: Erwin Pope, ca. 1909, unidentified process

1976.0315.0235: Young girl in dress, 1910, unidentified process

1976.0315.0236: Louisa Anderson, Half sister of Paul Anderson, 1910, platinum print 
1976.0315.0237: Woman wearing a fur coat and hat, 1910, unidentified process

1976.0315.0238: Young girl with bow in her hair, next to a doll, 1910, unidentified process

1976.0315.0239: Stanley Srachan, 1910, unidentified process

1976.0315.0240: Woman sitting in chair, ca. 1909, unidentified process

1976.0315.0241: Still life of statue, 1911, platinum print 


\section{PAUL LEWIS ANDERSON}

\section{CHLOROBROMIDE A}

1976.0315.0029: February: Rain, 1943, gelatin silver print

1976.0315.0045: The Night Mail, 1938, gelatin silver print

1976.0315.0094: Autumn Pattern, 1932, gelatin silver print

1976.0315.0138: The Little White House, 1943, gelatin silver print

1976.0315.0139: Mist along the Shore, 1914, gelatin silver print

1976.0315.0140: Sun on the Sea - Maine, 1915, gelatin silver print

1976.0315.0142: Surf at Monhegan 2, 1916, gelatin silver print

1976.0315.0143: Surf at Monhegan 4, 1916, gelatin silver print

1976.0315.0157: Winter in the Park, 1939, gelatin silver print

1976.0315.0189: The Dragon, 1915, gelatin silver print

1976.0315.0196: The White Sail - Barnegat, 1936, gelatin silver print

1976.0315.0198: The Harbor, Monhegan, 1916, gelatin silver print

1976.0315.0203: Waterfall in the Woods, 1940, gelatin silver print

1976.0315.0335: Still Life II, 1947, gelatin silver print

1976.0315.0370: Books and Roses, 1941, gelatin silver print

1976.0315.0376: Nasturtiums, 1944, gelatin silver print

1976.0315.0379: Maple Buds 1, 1943, gelatin silver print

1976.0315.0410: Snowballs 2, 1932, gelatin silver print

1976.0315.0474: Self-Portrait, 1942, gelatin silver print with gum overlay

1976.0315.0480: Solitaire, 1939, gelatin silver print

1976.0315.0481: Costume Portrait (Elmer C. Jackson), 1939, gelatin silver print 


\section{PAUL LEWIS ANDERSON}

\section{CHLOROBROMIDE B}

1976.0315.0014: Woman next to tree, 1916, Gelatin silver print

1976.0315.0028: East Canaan - Connecticut, 1915, gelatin silver print

1976.0315.0134: Five Islands - Maine, 1915, gelatin silver print

1976.0315.0135: Norfolk, Connecticut, 1915, gelatin silver print

1976.0315.0136: Bat. East Canaan - Norfolk, 1915, gelatin silver print

1976.0315.0145: Brook in Sunlight, 1915, gelatin silver print

1976.0315.0148: Five Islands - Maine, 1915, gelatin silver print

1976.0315.0151: Cornfield, 1915, gelatin silver print

1976.0315.0154: A Country Lane, 1915, gelatin silver print

1976.0315.0178: The Big White Cloud, 1939, gelatin silver print

1976.0315.0183: Sunset, Five Islands - Maine, 1915, gelatin silver print

1976.0315.0184: The Big White Cloud, 1931, gelatin silver print

1976.0315.0194: East Canaan, ca. 1915, gelatin silver print

1976.0315.0199: Five Islands - Maine, 1916, gelatin silver print

1976.0315.0213: A Farm-Yard in Rain, 1915, gelatin silver print

1976.0315.0215: East Canaan, 1915, gelatin silver print

1976.0315.0216: In the Berkshire Country, 1915, gelatin silver print

1976.0315.0441: Anne Brigman, ca. 1915, gelatin silver print 


\section{PAUL LEWIS ANDERSON}

CHLOROBROMIDE (Landscape, Cityscape, and Portrait)

1976.0315.0015: Lady in White, 1944, gelatin silver print

1976.0315.0040: New York Public Library - The Lion, 1909-1945, gelatin silver print

1976.0315.0056: Shadow Pattern - Night, 1939, gelatin silver print

1976.0315.0090: Willows - East Canaan, 1915, gelatin silver print

1976.0315.0099: Autumn Sunlight: No. 2, 1942, gelatin silver print

1976.0315.0102: Landscape, East Canaan, 1915, gelatin silver print

1976.0315.0103: Spring Mist, 1943, gelatin silver print

1976.0315.0114: Hoarfrost and Sun, 1942, gelatin silver print

1976.0315.0149: The Blackberry River, 1915, gelatin silver print

1976.0315.0155: Midsummer Haze, 1946, gelatin silver print

1976.0315.0158: Winter in the Park, 1938, gelatin silver print

1976.0315.0160: Winter in the Berkshires, 1917, gelatin silver print

1976.0315.0164: Snow, Ice, and Sun, 1916, gelatin silver print

1976.0315.0190: Early Morning on the Lake, 1942, gelatin silver print

1976.0315.0195: Barnegat Bay, 1936, gelatin silver print

1976.0315.0197: White Sails, 1916, gelatin silver print

1976.0315.0202: Waterfall in the Woods, 1932, gelatin silver print

1976.0315.0298: The Fountain Smith College, 1933, gelatin silver print

1976.0315.0315: Church: Amherst, Mass., 1934, gelatin silver print

1976.0315.0316: Church: Amherst, Mass., 1934, gelatin silver print

1976.0315.0427: Mary G. Anderson sitting in chair, ca. 1915, gelatin silver print 
1976.0315.0453: Lady with Parasol, 1909, gelatin silver print

1976.0315.0457: What do the Critics Say? 1938, gelatin silver print 


\section{PAUL LEWIS ANDERSON}

CHLOROBROMIDE (Still life, nature study)

1976.0315.0331: Chrysanthemums, 1949, gelatin silver print

1976.0315.0332: Still Life - Ivy, 1934, gelatin silver print

1976.0315.0333: Hollyhocks, 1949, gelatin silver print

1976.0315.0334: Snowballs, 1946, gelatin silver print

1976.0315.0337: Still Life I, 1949, gelatin silver print

1976.0315.0339: Still Life: Huckleberry Branch, 1947, gelatin silver print

1976.0315.0341: Hugonis Rose, 1946, gelatin silver print

1976.0315.0344: Tulips, 1945, gelatin silver print

1976.0315.0346: Pear Blossoms, 1946, gelatin silver print

1976.0315.0347: Hugonis Rose II, 1946, gelatin silver print

1976.0315.0348: Pear Blossoms, 1946, gelatin silver print

1976.0315.0349: Pear Blossoms, 1946, gelatin silver print

1976.0315.0350: Pear Blossoms, 1946, gelatin silver print

1976.0315.0351: Pear Blossoms, 1946, gelatin silver print

1976.0315.0354: Hugonis Rose 2, 1946, gelatin silver print

1976.0315.0355: The Venus De Milo, 1946, gelatin silver print

1976.0315.0357: Dandelions, 1947, gelatin silver print

1976.0315.0369: Books and Roses, 1946, gelatin silver print

1976.0315.0374: Nasturtiums, 1944, gelatin silver print

1976.0315.0375: Nasturtiums, 1944, gelatin silver print

1976.0315.0378: Maple Buds, 1943, gelatin silver print 
1976.0315.0399: Dahlia, 1933, gelatin silver print 


\section{PAUL LEWIS ANDERSON}

\section{GELATIN SILVER}

1976.0315.0041: Lackawana Station, 1909, gelatin silver print

1976.0315.0042: Shadow Pattern - Day, ca. 1910, gelatin silver print

1976.0315.0053: View of a tower with woman and child in foreground, 1909, gelatin silver print

1976.0315.0062: Union Square, 1909, gelatin silver print

1976.0315.0066: Raymond Boulevard - Newark, 1939, gelatin silver print

1976.0315.0072: The Mid-Hudson Bridge, 1909, gelatin silver print

1976.0315.0095: Morning Sunlight, Landscape, ca. 1915, gelatin silver print

1976.0315.0141: Waves crashing against rocks, 1916, gelatin silver print

1976.0315.0166: Trees in the snow, ca.1915, gelatin silver print

1976.0315.0193: Follow My Leader, ca. 1915, gelatin silver print

1976.0315.0329: Maples in Sun, 1943, gelatin silver print

1976.0315.0394: Still Life - The Spider Plant, 1936, gelatin silver print

1976.0315.0401: Chrysanthemums, 1942, gelatin silver print

1976.0315.0402: Chrysanthemums, 1942, gelatin silver print

1976.0315.0411: Still Life, ca. 1920, gelatin silver print

1976.0315.0416: M.G.A., ca. 1910, gelatin silver print

1976.0315.0446: Erwin Pope, ca. 1910, gelatin silver print

1976.0315.0449: P.L.A. Self-Portrait, ca. 1911, gelatin silver print

1976.0315.0454: Ianthe Green Jennings Watson - Mary Green Anderson, ca. 1910, gelatin silver

print

1976.0315.0483: N.Y. Public Library - Karl Struss and Model, ca. 1915, gelatin silver print 
1976.0315.0484: Penn. Station - Karl Struss and Model, ca. 1915, gelatin silver print 1976.0315.0485: Penn. Station - Karl Struss and Model, ca. 1915, gelatin silver print 1976.0315.0486: N.Y. Public Library - Karl Struss and Model, ca.1915, gelatin silver print 1976.0315.0487: N.Y. Public Library - Karl Struss and Model, ca. 1915, gelatin silver print 


\section{PAUL LEWIS ANDERSON \\ MULTIPLE GUM}

1976.0315.0005: A Dryad, 1936, gum bichromate print

1976.0315.0020: Lady in a Garden, 1943, gum bichromate print

1976.0315.0021: Lady in a Garden, 1943, gum bichromate print

1976.0315.0023: La Beale Isoud, 1915, gum bichromate print

1976.0315.0032: Fantasy, 1910, gum bichromate print

1976.0315.0057: Shadows and Sun, 1942, gum bichromate print

1976.0315.0107: Tree-Northfield Road, 1911, platinum print

1976.0315.0144: The Lake, Evening, 1911, gum bichromate print

1976.0315.0150: The White House beside the Lake, 1911, gum bichromate print

1976.0315.0306: Burton Hall - Smith College, 1932, gum bichromate print

1976.0315.0307: Sage Hall, Smith College, 1935, gum bichromate print

1976.0315.0317: Monday Morning, 1933, gum bichromate print

1976.0315.0396: The Witch Tree, 1943, gum bichromate print

1976.0315.0409: Still Life, 1932, gum bichromate print

1976.0315.0430: Scene from "The Highroad", 1933, gum bichromate print

1976.0315.0431: Scene from "The Highroad," Act III, 1935, gum bichromate print

1976.0315.0476: A.J.P Pionnie, 1935, gum bichromate print

1976.0315.0477: Raymond N. Getches, 1934, gum bichromate print

1976.0315.0607: Monday Morning, 1935, gum bichromate print 


\section{PAUL LEWIS ANDERSON \\ GUM, GUM PLATNIUM, GUM PALLADIUM}

1976.0315.0004: A dryad, 1910, gum bichromate print

1976.0315.0018: The Arch, 1909, gum bichromate print

1976.0315.0019: The Arch, 1911, gum bichromate over platinum print

1976.0315.0030: February: Snow, 1943, gum bichromate print

1976.0315.0031: A Dryad, 1910, gum bichromate print

1976.0315.0043: The Fountain in Llewellyn Park, 1909, gum bichromate over platinum print

1976.0315.0048: Cathedral of St. John the Divine, 1909, gum bichromate over platinum print

1976.0315.0065: The Manhattan Bridge, 1909, gum bichromate over platinum print

1976.0315.0073: The Brooklyn Bridge - Tug Boat, 1911, gum bichromate over platinum print

1976.0315.0076: The Passaic River at Newark, 1911, gum bichromate over platinum print

1976.0315.0078: The Hudson River: The Ferry-boat, ca. 1915, gum bichromate print

1976.0315.0081: High Bridge, Snow, ca. 1915, gum bichromate over platinum print [?]

1976.0315.0159: February: Snow, 1943, gum bichromate print

1976.0315.0180: Storm - East Canaan, ca. 1920, gum bichromate over platinum print

1976.0315.0181: From My Window, ca. 1911, gum bichromate over platinum print [?]

1976.0315.0182: Landscape, trees and cloud, 1911, gum bichromate print

1976.0315.0395: The Witch Tree, 1944, gum bichromate over palladium print

1976.0315.0413: Mary Anderson - Feather Boa and Scarf, 1911, gum bichromate over platinum print

1976.0315.0423: A Connecticut Farmer - Henry Stevens, 1917, gum bichromate over platinum print 
1976.0315.0440: Portrait of Dr. Frank B. Mitchell, 1910, gum bichromate over platinum print 1976.0315.0470: Portrait of W.J. Baer, 1915, gum bichromate over platinum print 1976.0315.0472: Sir Douglas Mawson, 1915, gum bichromate over platinum print 1976.0315.0478: Dr. E.A. Railey, ca. 1915, gum bichromate over platinum print 


\section{PAUL LEWIS ANDERSON}

\section{HESS-IVES / PHOTOGRAVURE}

1976.0315.0482: Pinky Anderson, ca. 1915, color print, assembly (Hess-Ives) process

1976.0315.0424: Portrait of Henry R. Poore, ca. 1913, photogravure 


\section{PAUL LEWIS ANDERSON \\ OIL, BROMOIL, CARBON, CARBRO}

1976.0315.0011: The Divine Week, 1916, oil print

1976.0315.0050: Nocturne in Brown and Black, 1931, carbon print

1976.0315.0061: Union Square, ca. 1915, carbon print

1976.0315.0079: Mid-Hudson Bridge, ca. 1915, bromoil print

1976.0315.0093: Trees in the forest, 1917, bromoil print

1976.0315.0096: Winter in the Berkshires, 1915, bromoil print

1976.0315.0108: The Lake of the Twinkling Lights, 1915, carbon print

1976.0315.0165: The Brook - Winter, 1920, carbon print

1976.0315.0185: The Lonely Tree, 1911, oil print

1976.0315.0187: The Storm, ca. 1915, carbon print

1976.0315.0211: The Lake, Rosebrook, 1915, carbon print

1976.0315.0296: Smith College: The Athletic Field, 1934, carbon print

1976.0315.0297: The Fountain - Smith College, 1934, carbon print

1976.0315.0299: Smith College: The Observatory, 1934, carbon print

1976.0315.0314: Harvey Cottage, 1913, carbon print

1976.0315.0340: Still Life in the Classic Manner, 1935, carbon print

1976.0315.0400: A Dahlia, 1931, carbon print

1976.0315.0422: Henry R. Poore, 1913, carbon print

1976.0315.0428: Paul L. Anderson, ca. 1915, oil print

1976.0315.0429: Portrait of Fred R. Hood, 1911, carbon print

1976.0315.0433: Portrait of Dorothy Cardley, 1917, bromoil print 
1976.0315.0443: Henry R. Poore, ca. 1913, carbon print

1976.0315.0460: Pinkie, ca. 1914, bromoil print

1976.0315.0461: Pinkie, 1914, bromoil print

1976.0315.0468: Elizabeth Hammacher, 1916, oil print

1976.0315.0473: Portrait of an Artist (Henry R. Poore), 1913, carbon print 


\section{PAUL LEWIS ANDERSON}

\section{PALLADIUM}

1976.0315.0001: From My Window: Sunday Afternoon, 1943, palladium print

1976.0315.0002: From My Window: Sunday Afternoon, 1943, palladium print

1976.0315.0003: The Brook, 1910, palladium print

1976.0315.0006: A Dryad, 1917, palladium print

1976.0315.0016: Lady in a Garden II, 1952, palladium print

1976.0315.0017: From My Window, 1951, palladium print

1976.0315.0033: A Doorway to Grammercy Square, ca. 1916, palladium print

1976.0315.0034: A Doorway to Grammercy Square, ca. 1916, palladium print

1976.0315.0035: A Doorway to Grammercy Square, ca. 1916, palladium print

1976.0315.0175: Evening in the Berkshires, 1917, palladium print

1976.0315.0191: The Swan, 1942, palladium print

1976.0315.0192: The Swan, 1942, palladium print

1976.0315.0320: Cleaning Silver, 1947, palladium print

1976.0315.0330: Maples in Sunlight, 1943, palladium print

1976.0315.0336: Souvenir de Claudius Pernet, 1946, palladium print

1976.0315.0338: Huckleberry Branch, 1947, palladium print

1976.0315.0342: Roses on table in sunlight, 1951, palladium print

1976.0315.0343: Roses, 1946, palladium print

1976.0315.0345: Dahlias, 1947, palladium print

1976.0315.0356: Globe Thistles, 1947, palladium print

1976.0315.0358: Daffodils, 1947, palladium print 
1976.0315.0359: Tanagra Figurine, ca. 1916, palladium print

1976.0315.0360: The Little Model, 1916, palladium print

1976.0315.0362: Roses in Sunlight, 1944, palladium print

1976.0315.0377: Still Life: Venus and the Vine, 1938, palladium print

1976.0315.0408: Still Life: The Venus De Milo, 1928, palladium print

1976.0315.0426: Bessie, 1916, palladium print

1976.0315.0475: Portrait of Bertrand H. Wentworth, ca. 1916, palladium print 


\section{PAUL LEWIS ANDERSON}

PLATINUM A

1976.0315.0010: The Lake, Orange Park - Evening, ca. 1920, platinum print

1976.0315.0038: Street Scene in Philadelphia, ca. 1915, platinum print

1976.0315.0044: Metropolitan Tower - from Grammercy Square, 1909, platinum print

1976.0315.0046: The Little Church around the Corner, 1909, platinum print

1976.0315.0055: Newark - From the Public Library, 1911, platinum print

1976.0315.0058: Washington Arch, ca. 1915, platinum print

1976.0315.0059: Union Theological Seminary, 1909, platinum print

1976.0315.0060: The Last Horse-car, ca. 1915, platinum print

1976.0315.0071: The Fountain - Semerville, ca. 1915, platinum print

1976.0315.0077: Early Morning on the Hudson, 1915, platinum print

1976.0315.0080: New York in Winter, 1915, platinum print

1976.0315.0092: Landscape: East Canaan, 1935, platinum print

1976.0315.0137: A Winter Night, 1928, platinum print

1976.0315.0156: Ice and Snow 36, 1915, platinum print

1976.0315.0161: Two Trees: Snow, ca. 1925, platinum print

1976.0315.0162: Peter's Brook - Somerville Winter, 1909, platinum print

1976.0315.0163: The Path - Snow, 1910, platinum print

1976.0315.0172: Winter - New Hope, ca. 1909, platinum print

1976.0315.0173: Winter, New Hope, ca. 1909, platinum print

1976.0315.0188: Trees and sky, ca. 1915, platinum print

1976.0315.0414: Mary Anderson - White Dress, 1909, platinum print 
1976.0315.0415: Mary G. Anderson, ca. 1910, platinum print

1976.0315.0417: Mary Anderson - Black Lace Evening Gown, 1911, platinum print

1976.0315.0432: Gladys Eyre and Mrs. Arthur Anderson, 1917, platinum print

1976.0315.0434: Portrait of Delight Weston, 1916, platinum print

1976.0315.0435: Gladys Eyre, 1917, platinum print

1976.0315.0436: Gladys Eyre, 1917, platinum print

1976.0315.0437: Gladys Eyre, 1917, platinum print

1976.0315.0438: Gladys Eyre, 1917, platinum print

1976.0315.0439: Gladys Eyre, 1917, platinum print

1976.0315.0442: Henry R. Poore, 1913, platinum print

1976.0315.0444: P.L.A In the Doorway of Harvey Cottage, 1896, platinum print

1976.0315.0450: P.L.A - Self-portrait, ca. 1911, platinum print

1976.0315.0451: P.L.A - Self-portrait, 1911, platinum print

1976.0315.0452: Clarence H. White School of Photography: Group at Summer School, ca. 1916, platinum print

1976.0315.0459: Pinkie, ca. 1914, platinum print 


\section{PAUL LEWIS ANDERSON}

\section{PLATINUM B}

1976.0315.0022: The Bird Song, 1915, platinum print

1976.0315.0023: La Beale Isoud, 1915, gum bichromate print

1976.0315.0047: In the Boston Public Library, 1909, platinum print

1976.0315.0070: Branch Brook Park, 1911, platinum print

1976.0315.0091: Landscape: East Canaan, ca. 1915, platinum print

1976.0315.0097: Landscape, East Canaan, ca. 1915, platinum print

1976.0315.0098: Landscape, East Canaan, ca. 1915, platinum print

1976.0315.0106: The Lake, Orange Park - Evening, ca. 1910, platinum print

1976.0315.0147: The Blackberry River, 1915, platinum print

1976.0315.0176: Landscape, E. Canaan, 1914, platinum print

1976.0315.0177: Very Like a Camel, ca. 1915, platinum print

1976.0315.0179: Morning in the Hills, 1914, platinum print

1976.0315.0186: The Lonely Tree, ca. 1910, platinum print

1976.0315.0212: The Canaan Valley Road, 1914, platinum print

1976.0315.0327: Gossip, ca. 1915, platinum print

1976.0315.0419: Mary G. Anderson, 1910, platinum print

1976.0315.0425: Dorothy Graham, 1916, platinum print

1976.0315.0445: Karl Struss, ca. 1911, platinum print

1976.0315.0458: M.G.A and Pinkie, ca. 1914, platinum print

1976.0315.0462: Pinkie, ca. 1919, platinum print

1976.0315.0463: Pinkie, 1914, platinum print 


\section{PAUL LEWIS ANDERSON}

\section{PLATINUM C}

1976.0315.0036: Cars going through a tunnel, ca. 1909, platinum print

1976.0315.0037: Interior view of large concourse, ca. 1910, platinum print

1976.0315.0039: Harbor, ca. 1910, platinum print

1976.0315.0049: Woman boarding double-decker bus, 1909, platinum print

1976.0315.0051: The Gas Tank, 1911, platinum print

1976.0315.0052: Under the Brooklyn Bridge, 1909, platinum print

1976.0315.0054: Man sweeping in entrance to train station, 1909, platinum print

1976.0315.0146: Reflections of trees on water, 1910, platinum print

1976.0315.0174: Winter, 1909, platinum print

1976.0315.0214: The Valley of the Oranges, 1910, platinum print

1976.0315.0328: Mary Green Anderson, 1911, platinum print

1976.0315.0418: Mary G. Anderson, 1911, platinum print

1976.0315.0420: M.G.A., ca. 1910, platinum print

1976.0315.0421: Portrait of Mary G. Anderson, ca. 1910, platinum print

1976.0315.0464: Pinkie, 1915, platinum print

1976.0315.0465: Pinkie, ca. 1915, platinum print

1976.0315.0466: Portrait of Clarence H. White by P.L.A., ca. 1915, platinum print

1976.0315.0467: Max Weber, 1914, platinum print

1976.0315.0469: Portrait of William J. Baer, 1915, platinum print

1976.0315.0471: Portrait of William J. Baer, ca. 1915, platinum print

1976.0315.0479: Ruth Davis, 1922, platinum print 


\section{PAUL LEWIS ANDERSON}

\section{SAME IMAGE TWO DIFFERENT PROCESSES}

(Chlorobromide and Palladium)

1976.0315.0012: The Driving Wind, 1916, gelatin silver print

1976.0315.0013: The Driving Wind, 1916, palladium print

1976.0315.0200: The Waterfall, 1942, gelatin silver print

1976.0315.0201: The Waterfall, 1942, palladium print

1976.0315.0308: Home Portrait - Ruth Anderson, 1940, gelatin silver print

1976.0315.0309: Home Portrait - Ruth Anderson, 1940, palladium print

1976.0315.0310: Home Portrait - Ruth Anderson, 1940, gelatin silver print

1976.0315.0352: Snowballs, 1948, gelatin silver print

1976.0315.0353: Snowballs, 1947, palladium print

1976.0315.0371: Still Life: Chinese Laterns, 1944, palladium print

1976.0315.0372: Still Life: Chinese Lanterns, 1944, gelatin silver print

1976.0315.0373: Still Life: Chinese Lanterns, 1944, gelatin silver print

1976.0315.0380: Vine in Sunlight, 1944, gelatin silver print

1976.0315.0381: Vine in Sunlight, ca. 1944, palladium print

1976.0315.0388: Vine in Sunlight, ca. 1944, palladium print 


\section{PAUL LEWIS ANDERSON}

\section{SAME IMAGE TWO DIFFERENT PROCESS}

(Nature study, Still Life, and Portrait)

1976.0315.0311: Tausendschon Rose, 1942, gelatin silver print

1976.0315.0312: Tausendschon Rose, ca. 1942, carbon print

1976.0315.0313: Tausendschon Rose, 1941, gelatin silver print

1976.0315.0361: Roses in Sunlight, 1944, palladium print

1976.0315.0363: Roses in Sunlight, 1944, gelatin silver print

1976.0315.0364: Roses in Sunlight, 1943, palladium print

1976.0315.0365: Roses in Sunlight, 1944, palladium print

1976.0315.0366: Roses in Sunlight, 1943, gelatin silver print

1976.0315.0367: Roses in Sunlight, 1944, gelatin silver print

1976.0315.0368: Roses in Sunlight, 1944, gelatin silver print

1976.0315.0392: Maple Branch 1, ca.1943, gelatin silver print

1976.0315.0393: Maple Branch in Sunlight, 1943, gelatin silver print

1976.0315.0397: Poppies, 1944, gelatin silver print

1976.0315.0398: Poppies, 1944, gelatin silver print

1976.0315.0455: MGA in Silk Dress, ca. 1910, platinum print

1976.0315.0456: Mary Green Anderson in Silk Dress, ca. 1910, carbon print 


\title{
PAUL LEWIS ANDERSON
}

\section{SAME IMAGE TWO DIFFERENT PROCESS}

\author{
(Landscape and Cityscape)
}

1976.0315.0063: Approach to the Queensboro bridge, 1909, unidentified process

1976.0315.0064: Approach to the Queensborough Bridge, ca. 1909, platinum print

1976.0315.0074: Mist on the Hudson 2, 1915, gelatin silver print

1976.0315.0075: Mist on the Hudson, 1915, gelatin silver print

1976.0315.0100: Autumn Sunlight: No. 1, 1942, gelatin silver print

1976.0315.0101: Autumn Sunlight, 1942, gelatin silver print

1976.0315.0104: Fog Pattern, 1943, gelatin silver print

1976.0315.0105: Fog Pattern, 1943, gum bichromate print

1976.0315.0115: Willow Beside the Brook, 1915, gum bichromate over platinum print

1976.0315.0116: WIllow Beside the Brook, 1915, gum bichromate over platinum print

1976.0315.0152: A Country Road, 1915, gum bichromate over platinum print

1976.0315.0153: A Country Road, 1915, multiple gum print

1976.0315.0167: Sunlight and Sun, 1908, gum bichromate over platinum print

1976.0315.0168: Winter in the Woods, ca. 1908, platinum print

1976.0315.0300: The Grecourt gate in fog at Smith College, 1934, unidentified process

1976.0315.0301: Smith College: The Grecourt Gate, 1933, bromoil print

1976.0315.0318: A Connecticut farmhouse, 1917, photogravure

1976.0315.0319: A Connecticut Farmhouse, 1917, palladium print 


\section{PAUL LEWIS ANDERSON}

SAME IMAGE TWO DIFFERENT PROCESSES (15 x 12)

1976.0315.0088: Springtime Pattern, 1943, gum bichromate print

1976.0315.0089: Springtime Pattern, ca. 1943, palladium print

1976.0315.0109: Willows, Summer, 1933, gum bichromate print

1976.0315.0110: Willows; Summer, ca. 1935, palladium print

1976.0315.0111: Willows, Summer, 1936, palladium print

1976.0315.0112: Willows, Summer, ca. 1940, gum bichromate print

1976.0315.0113: Willows, Summer, 1936, palladium print 


\section{PAUL LEWIS ANDERSON}

\section{SAME IMAGE THREE DIFFERENT PROCESS}

1976.0315.0007: The Sun Worshippers, ca. 1916, palladium print

1976.0315.0008: The Sun Worshippers, 1916, palladium print

1976.0315.0009: The Sun Worshippers, 1915, gum bichromate print

1976.0315.0067: Shadow Pattern - Day, 1939, gelatin silver print

1976.0315.0068: Shadow Pattern - Day, 1939, unidentified process

1976.0315.0069: Shadow Pattern - Day, 1939, gelatin silver print

1976.0315.0117: Willows, Autumn, 1933, gum bichromate print

1976.0315.0118: Willows, Autumn, 1933, gum bichromate print

1976.0315.0119: Willows, Autumn, 1936, palladium print

1976.0315.0120: Willows, Autumn, 1936, gelatin silver print

1976.0315.0128: A Berkshire Meadow, 1920, unidentified process

1976.0315.0129: A Berkshire Meadow, 1920, unidentified process

1976.0315.0130: A Berkshire Meadow, 1920, gum bichromate over palladium print

1976.0315.0131: A Berkshire Meadow, 1916, gelatin silver print

1976.0315.0132: A Berkshire Meadow, 1920, palladium print

1976.0315.0133: A Berkshire Meadow, 1920, gelatin silver print

1976.0315.0169: Winter in the Berkshires, 1917, gelatin silver print

1976.0315.0170: Winter in the Berkshires, 1917, unidentified process

1976.0315.0171: Snow in the Berkshires, 1916, gelatin silver print

1976.0315.0302: Smith College - Sage Hall, Night, 1935, gum bichromate over palladium print

1976.0315.0303: Smith College - Sage Hall, Night, 1935, carbon print 
1976.0315.0304: Smith College - Sage Hall, Night, 1935, gelatin silver print with gum overlay 1976.0315.0305: Smith College - Sage Hall, Night, 1935, gum bichromate over palladium print 


\section{PAUL LEWIS ANDERSON}

\section{SAME IMAGE FOUR DIFFERENT PROCESS}

1976.0315.0024: Guenever, 1916, gelatin silver print with gum overlay

1976.0315.0025: Guenever, 1916, carbon print

1976.0315.0026: Guenever, 1916, gum bichromate print

1976.0315.0027: Guenever, 1916, gum bichromate print

1976.0315.0382: Vine in Sunlight, 1944, gum bichromate print

1976.0315.0383: Vine in Sunlight, 1944, gelatin silver print

1976.0315.0384: Vine in Sunlight, 1944, gelatin silver print

1976.0315.0385: Vine in Sunlight 1, 1944, gelatin silver print

1976.0315.0386: Vine in Sunlight, 1944, palladium print

1976.0315.0387: Vine in Sunlight, 1944, gum bichromate print

1976.0315.0389: Vine in Sunlight, 1944, gelatin silver print

1976.0315.0390: Vine in Sunlight, 1944, gum bichromate over palladium print

1976.0315.0391: Vine in Sunlight, 1944, gelatin silver print

1976.0315.0403: Grapes, 1909, gelatin silver print

1976.0315.0404: Grapes, 1909, gum bichromate print

1976.0315.0405: Grapes, 1909, gelatin silver print

1976.0315.0406: Grapes, 1909, gelatin silver print

1976.0315.0407: Grapes, 1909, gum bichromate print 


\section{PAUL LEWIS ANDERSON}

\section{SAME IMAGE DIFFERENT PROCESS (20 x 24)}

1976.0315.0082: October Morning in the Berkshires, 1916, gelatin silver print

1976.0315.0083: October Morning in the Berkshires, 1916, gum bichromate print

1976.0315.0084: October Morning in the Berkshires, 1916, gum bichromate print

1976.0315.0085: October Morning in the Berkshires, 1916, unidentified process

1976.0315.0086: October Morning in the Berkshires, ca. 1916, gelatin silver print

1976.0315.0087: October Morning in the Berkshires, 1916, gelatin silver print

1976.0315.0088: Springtime Pattern, 1943, gum bichromate print

1976.0315.0121: Smith College: Paradise Pond, 1934, gelatin silver print with gum overlay

1976.0315.0122: Smith College: Paradise Road, 1934, palladium print

1976.0315.0123: Paradise Pond, Smith College, 1932, gum bichromate print

1976.0315.0124: Paradise Pond, 1932, gelatin silver print

1976.0315.0125: Smith College: Paradise Pond, 1932, gum bichromate print

1976.0315.0126: Paradise Pond, 1932, bromoil print

1976.0315.0127: Smith College: Paradise Road, 1932, palladium print

1976.0315.0204: Evening on a Berkshire Farm, 1916, gum bichromate print

1976.0315.0205: Evening on a Berkshire Farm, 1916, palladium print

1976.0315.0206: Evening on a Berkshire Farm, ca. 1916, carbon print

1976.0315.0207: Evening on a Berkshire Farm, 1916, gum bichromate over palladium print

1976.0315.0208: Evening on a Berkshire Farm, 1941, gelatin silver print

1976.0315.0209: Evening on a Berkshire Farm, 1941, carbon print

1976.0315.0210: Evening on a Berkshire Farm, 1941, carbon print 
1976.0315.0321: Sunday Morning, 1939, gelatin silver print

1976.0315.0322: Sunday Morning, 1944, palladium print

1976.0315.0323: Sunday Morning, 1940, gelatin silver print

1976.0315.0324: Sunday Morning, 1939, gelatin silver print

1976.0315.0325: Sunday Morning, 1939, palladium print

1976.0315.0326: Sunday Morning, 1939, gelatin silver print

1976.0315.0403: Grapes, 1909, gelatin silver print 


\section{PAUL LEWIS ANDERSON}

SMITH COLLEGE ALBUMS

1976.0315.0242-0258: SMITH COLLEGE, VOL. 1, 1932, GELATIN SILVER PRINTS

1976.0315.0242: The Grecourt Gate, 1932, gelatin silver print

1976.0315.0243: The Clock Tower, 1934, gelatin silver print

1976.0315.0244: Seeyle Hall, 1933, gelatin silver print

1976.0315.0245: The Library, 1932, gelatin silver print

1976.0315.0246: Burton Hall, 1932, gelatin silver print

1976.0315.0247: The Fountain, 1933, gelatin silver print

1976.0315.0248: The Presidents House, 1933, gelatin silver print

1976.0315.0249: The Observatory, 1933, gelatin silver print

1976.0315.0250: The Grecourt Gate - September, 1933, gelatin silver print

1976.0315.0251: Into the Quad, 1932, gelatin silver print

1976.0315.0252: The Arcade, 1932, gelatin silver print

1976.0315.0253: The Lamp-post, 1932, gelatin silver print

1976.0315.0254: Stairway in the Quad - Day, 1933, gelatin silver print

1976.0315.0255: A Reception Room - The Sub-Freshman, 1933, gelatin silver print

1976.0315.0256: Out from the Quad, 1932, gelatin silver print

1976.0315.0257: The Letter Home, 1933, gelatin silver print

1976.0315.0258: After Last Chapel, 1934, gelatin silver print

1976.0315.0259-0295: SMITH COLLEGE, VOLUME 2, 1935, CARBON PRINT (FRESSON)

1976.0315.0259: The Clock Tower, ca. 1935, carbon print 
1976.0315.0260: The Grecourt Gate - November, ca. 1935, carbon print

1976.0315.0261: The Grecourt Gate - September, ca. 1935, carbon print

1976.0315.0262: College Hall, ca. 1935, carbon print

1976.0315.0263: Seelye Hall, ca. 1935, carbon print

1976.0315.0264: The Letter Home, ca. 1935, carbon print

1976.0315.0265: Washburn House - In the Classic Manner, ca. 1935, carbon print

1976.0315.0266: Washburn House - In the Modern Manner, ca. 1935, carbon print

1976.0315.0267: Lilly Hall, ca. 1935, carbon print

1976.0315.0268: Mr. Kelly, ca. 1935, carbon print

1976.0315.0269: The Library - Day, ca. 1935, carbon print

1976.0315.0270: The Library - Night, ca. 1935, gum platinum print

1976.0315.0271: Burton Hall, ca. 1935, carbon print

1976.0315.0272: The Fountain, ca. 1935, carbon print

1976.0315.0273: The President's House, ca. 1935, gum platinum print

1976.0315.0274: Paradise Pond, ca. 1935, carbon print

1976.0315.0275: The Quad Entrance - Looking In, ca. 1935, carbon print

1976.0315.0276: The Arcade, ca. 1935, carbon print

1976.0315.0277: Doorway to Martha Wilson House, ca. 1935, carbon print

1976.0315.0278: The Lamp-post, ca. 1935, carbon print

1976.0315.0279: Steps in the Quad - Day, ca. 1935, carbon print

1976.0315.0280: Entrance to Comstock and Wilder Houses, ca. 1935, carbon print

1976.0315.0281: The Sub-Freshman, ca. 1935, carbon print

1976.0315.0282: Steps in the Quad - Night, ca. 1935, gelatin silver print with gum overlay 
1976.0315.0283: The Quad Entrance - Looking Out, ca. 1935, carbon print

1976.0315.0284: The Athletic Field, ca. 1935, carbon print

1976.0315.0285: Water on the Dam, 1934, carbon print

1976.0315.0286: The Ivy Procession, 1934, carbon print

1976.0315.0287: The Alumea Sing, 1934, carbon print

1976.0315.0288: The Observatory, ca. 1935, gum platinum print

1976.0315.0289: After Last Chapel, ca. 1935, carbon print

1976.0315.0290: The Lamont Bridge, ca. 1935, gum platinum print

1976.0315.0291: Sage Hall - Night, ca. 1935, gum platinum print

1976.0315.0292: The Alumnea Gymnasium, ca. 1935, carbon print

1976.0315.0293: Steps at the Scott Gymnasium, ca. 1935, carbon print

1976.0315.0294: The Fountain, ca. 1935, gum platinum print

1976.0315.0295: Non Numera Nigi Horas Serenas, ca. 1935, gum platinum print 


\section{Section 3.1: Process Guide ${ }^{66}$}

For illustrations see Process Guide Examples, Section 3.2.

\section{Silver Based Processes}

Gelatin Silver: Even though Anderson sometimes decried the use of gelatin silver paper, this process is very well represented in his body of work. This was the most widely used process of the $20^{\text {th }}$ century. Anderson used the developing out method of the process. The image was exposed, by either contact or enlargement, onto a sheet of paper coated with a gelatin silver emulsion in which the light sensitive silver halide crystals are suspended in gelatin. At the time of exposure there is a chemical reaction, which results in a latent image forming on the paperno image is yet visible on the paper and it must be chemically developed out. When properly fixed and dried, the process has excellent stability. Anderson frequently used the Chlorobromide type of papers. In these papers, there is combination of silver chloride and bromide, which yields a softer, grey tone. He also used a number of different paper surfaces, textures, and tones.

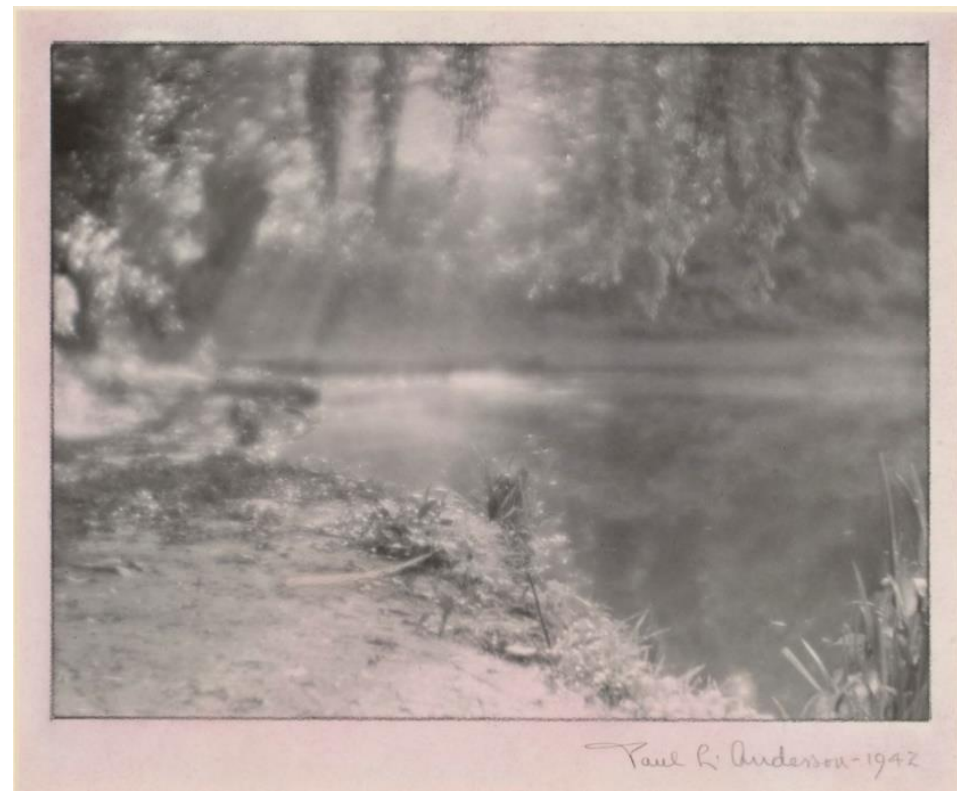

Figure 1 A gelatin silver chlorobromide print (1976.0315.0139)

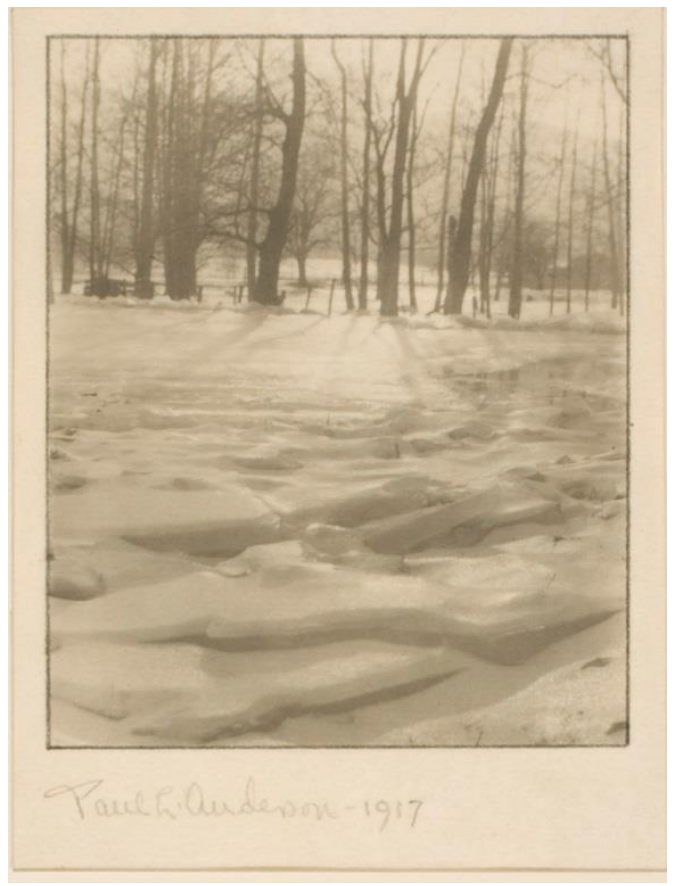

Figure 2 A gelatin silver bromide print (1976.0315.0160)

\footnotetext{
${ }^{66}$ Entries adapted from Sarah Kennel, In the Darkroom: An Illustrated guide to Photographic Processes before the
} Digital Age (Washington: National Gallery of Art, 2009). 


\section{Iron Based Processes}

Platinum: A common process during the Pictorialist movement and popular until the First World War. Prized for its tonal range and subtle treatment of gray tones, the process was popular with photographers. It is very well represented in Anderson's photographs and he used it extensively in the 1910s. The process is based on the light sensitivity of iron salts. The paper is brushed (or coated) with a solution of iron and platinum salts. When exposed to light the iron salts reduce and during development the iron salts react with the platinum salts reducing the platinum salts to platinum metal. Once developed, the print was very permanent and the platinum image embedded in the paper fibers. This allowed the platinum print to be layered with other processes. For instance, a gum over-platinum print has both gum bichromate and platinum on the print. Anderson did both regular platinum and also combined with other processes. In his body of work we find very neutral black platinum, platinum prints processed with mercury (to yield a sepia tone) and gum over platinum prints.

Palladium: Not as expensive as platinum, but producing a similar effect, palladium was also a common process and one that Anderson worked in frequently. Instead of using platinum salts, the process uses palladium salts. The process was introduced in 1916 due to the scarcity of platinum because of the First World War (it was used in the manufacture of bombs). These prints yield a warmer tone. Platinum can be combined with palladium to give a platinum-palladium print - although this mixing was not done until the mid-twentieth century.

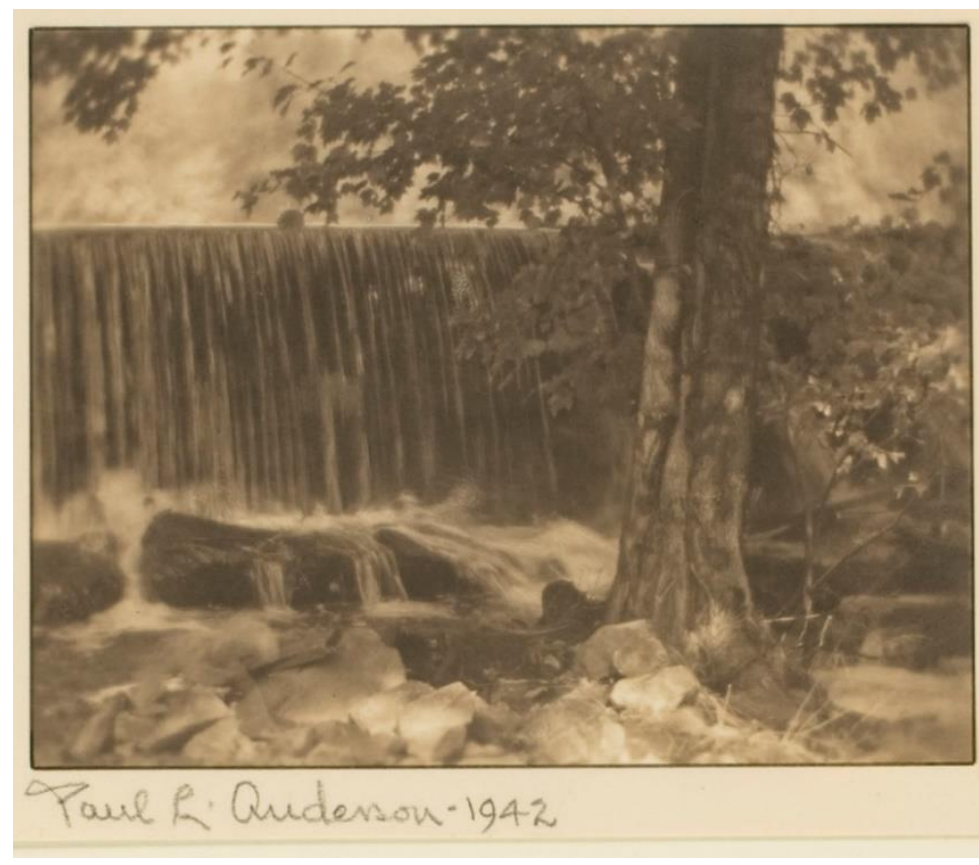

Figure 3 A palladium print (1976.0315.0201)

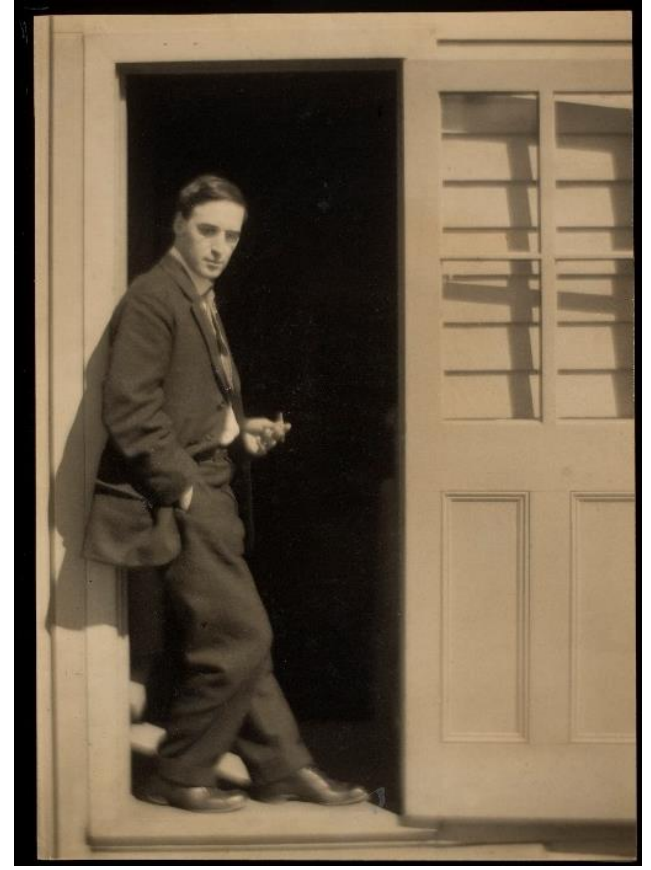

Figure 4 A platinum print (1976.0315.0444) 


\section{Pigment Based Processes}

This group of processes rely on the hardening action of dichromated colloids, such as gelatin and gum arabic. When the colloid is soaked in a solution of dichromate salts (usually potassium or ammonium dichromate) and exposed to light this makes the colloid tan, or harden, in relation to the amount of light exposure it receives. Areas which receive more light harden more and areas that do not receive light harden less so. When washed in warm water the dark areas remain insoluble (do not dissolve) and the lighter areas are washed away.

Gum bichromate print: The gum bichromate or gum print was favored by the Pictorialists because of its similarity to painting (a gum print can be manipulated with a brush). A sized paper is coated by either mixing the dichromate salt, gum arabic, and pigment together, and applying it to the paper, or by coating the paper first with dichromate salt and then applying a gum arabic and pigment mixture to the surface. This is contact printed with a negative. The image is then submerged in warm water and the soluble gum arabic (the gum in the lighter areas of the print) is washed away. At this stage, when the paper is wet, the pigmented gum arabic is very fragile and can be manipulated with brushes. This can be used to bring out highlights or add other aesthetic effects. Gum prints often went through multiple printings to build up the contrast of a print and Anderson noted on the versos how many printings he used (e.g. 3 printings). Anderson used gum frequently throughout his career.

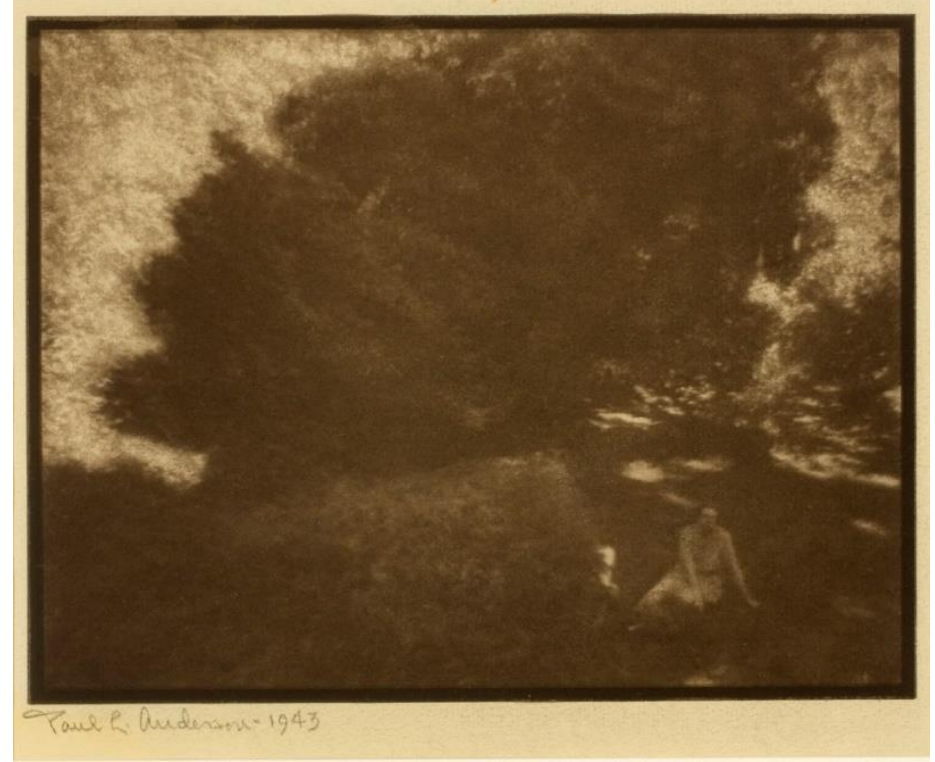

Figure 5 A gum bichromate print (1976.0315.0020)

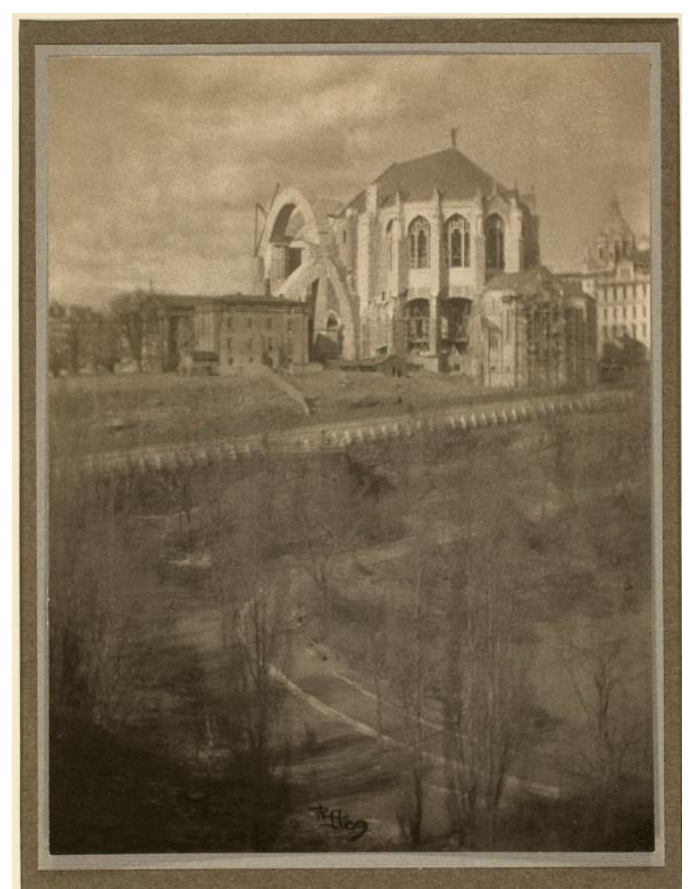

Figure 6 A gum-platinum print (1976.0315.0048) 


\section{Carbon and variants}

Carbon: Relying on the principle outlined above, this is a process made with pigmented gelatin. The negative is exposed in contact with a "tissue," a sheet of pigmented gelatin sensitized with dichromate salts. After the correct exposure time, the tissue is placed in cold water and "mated" with a sheet of sized (usually coated with gelatin) artist's paper. The pair is taken out, while sandwiched together, and weighed down for a number of minutes. After the pair is placed in warm water. Pigmented gelatin starts to dissolve and ooze out of the sides and the tissue is peeled off of the paper. Pigmented gelatin continues to be washed away and we are left with the final print that needs to be washed in cold water, and dried. This is a transfer process, where the image is transferred from the tissue to the final paper support. The image requires transferring because the gelatin hardens during exposure from the top down, meaning the mid-tones are insoluble on top, but soluble near the support. Transferring flips the gelatin so that the soluble part is on top. There is also double transfer, where the image is transferred twice to correct the orientation of the image - in single transfer the image is reversed left to right (e.g. words are backwards).

Fresson: This is a direct carbon method. The print is not transferred onto a separate sheet of paper, instead the pigmented gelatin remains on the same support in the final image. The negative is first exposed with the dichromate sensitized pigmented gelatin. This sheet is then washed in a slurry of water and sawdust. The coarseness of the sawdust creates a fine reticulation pattern that forms the mid-tones tones in the image and results in a unique appearance. This method, like regular carbon, is a contact process where the size of the original negative is the size of the final image. It is important to note that the Fresson process is propriety and was owned by the Fresson Company in France. Fresson papers were commercially available in Europe from 1900 to 1939 and in America from 1927 to 1939. Anderson used his process for the $2^{\text {nd }}$ volume of his Smith College Album.

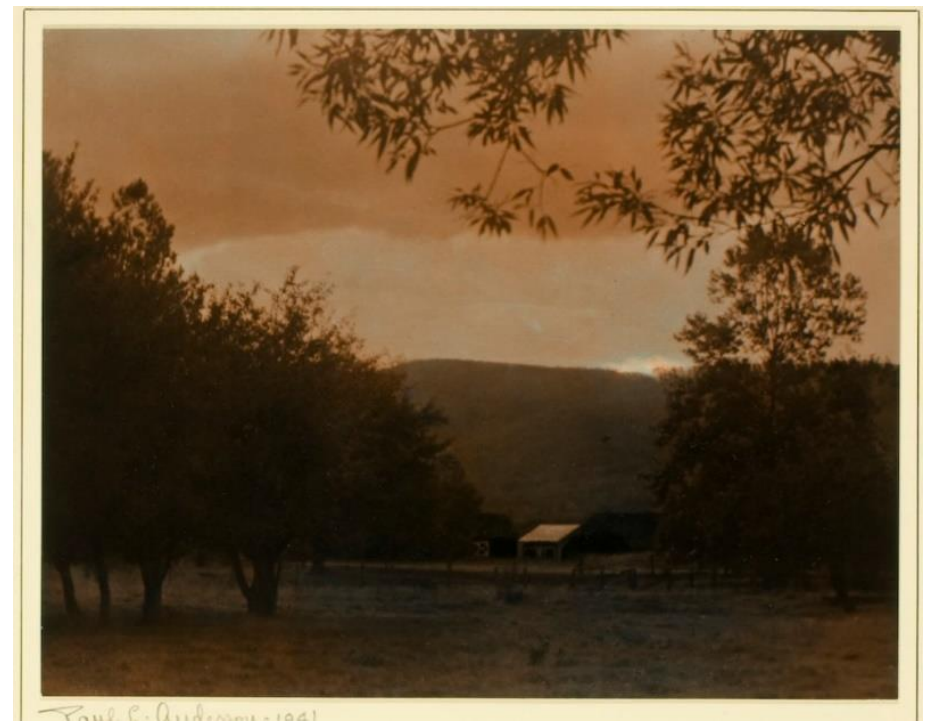

Figure 7 A carbon print (1976.0315.0209)

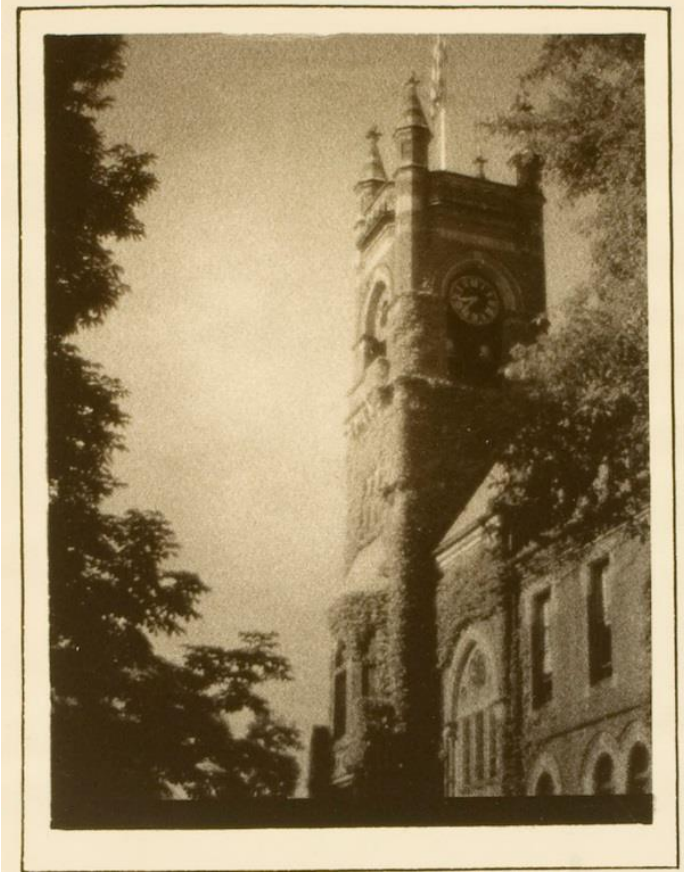

Figure 8 A Fresson (direct carbon) print (1976.0315.0259) 
Carbro: This method is very similar to carbon, except the steps for a final print are different. Instead of a negative, a silver bromide print is put in contact with a pigmented sheet of dichromated gelatin (carbon tissue). The negative is exposed by enlargement onto a gelatin silver print and developed normally. The carbon tissue is soaked (sensitized) in a solution of potassium dichromate, potassium bromide and potassium ferricyanide. The developed silver bromide print is soaked in cold water. The sensitized carbon tissue is squeegeed onto the silver bromide print. The silver causes the gelatin tissue to harden in proportion to the amount of silver present. The silver image simultaneously bleaches. Afterwards, the silver bromide print can be redeveloped and reused. Carbro is usually associated with color prints, but Anderson used carbro to make monochromatic photographs. Carbro has the great advantage of not relaying on the size of the negative, so the final carbro print can be made by enlargement with the bromide print.

Bromoil and Oil: An ink on paper process, the bromoil and oil process is made with dichromated gelatin and lithographer's ink. It relies on not only the hardening action of dichromated gelatin, but also the hydrophobic nature of oil (water and oil repel). A bromoil print is made by exposing a bromide print with a negative and then developing it in standard developing chemistry. It is then put into a solution of dichromate that tans the gelatin in relation to the amount of silver present while simultaneously bleaching the silver. It is then fixed and washed. The gelatin soaks in water in an inverse proportion, i.e. the shadows are hard and absorb the least amount of water, and the gelatin swells in the highlights. The print is then placed on a glass plate and inked with lithographer's ink. The ink is repelled by areas that are swollen the most with water (i.e. the highlights). The shadows and mid-tones accept the ink in relation to how swollen those areas are. The ink is built up in several layers, allowing for control by the photographer to highlight or darken specific areas. An oil print is the same, but instead a negative is put into a contact with a regular sheet of artist's paper coated with gelatin and sensitized with dichromate. Anderson used both bromoil and oil and his prints have a characteristic ink on paper aesthetic.

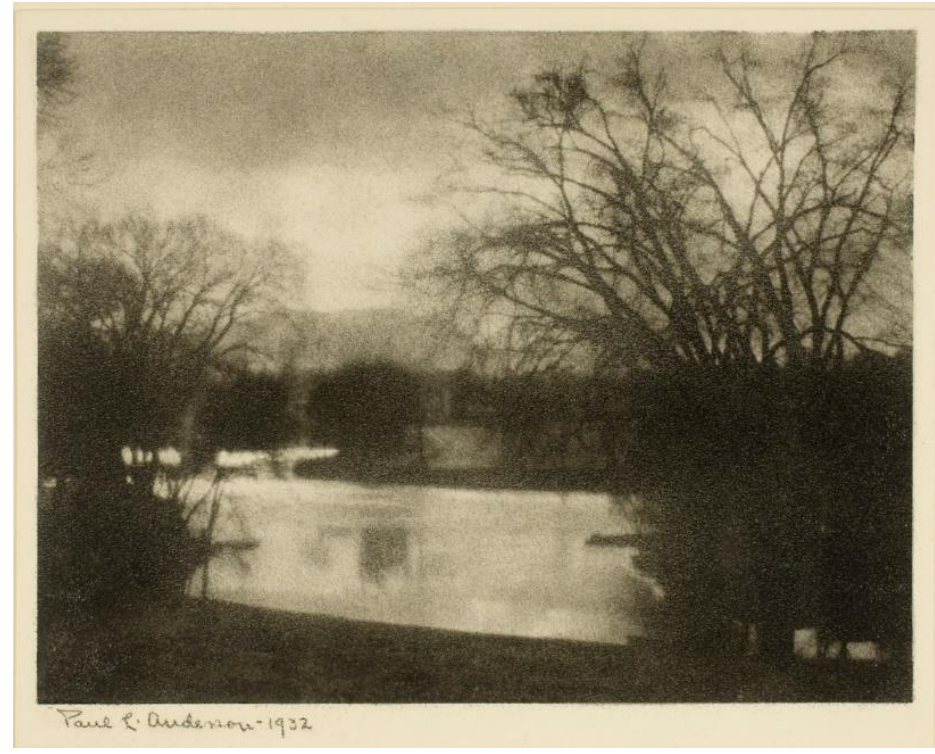

Figure 10 A bromoil print (1976.0315.0126)

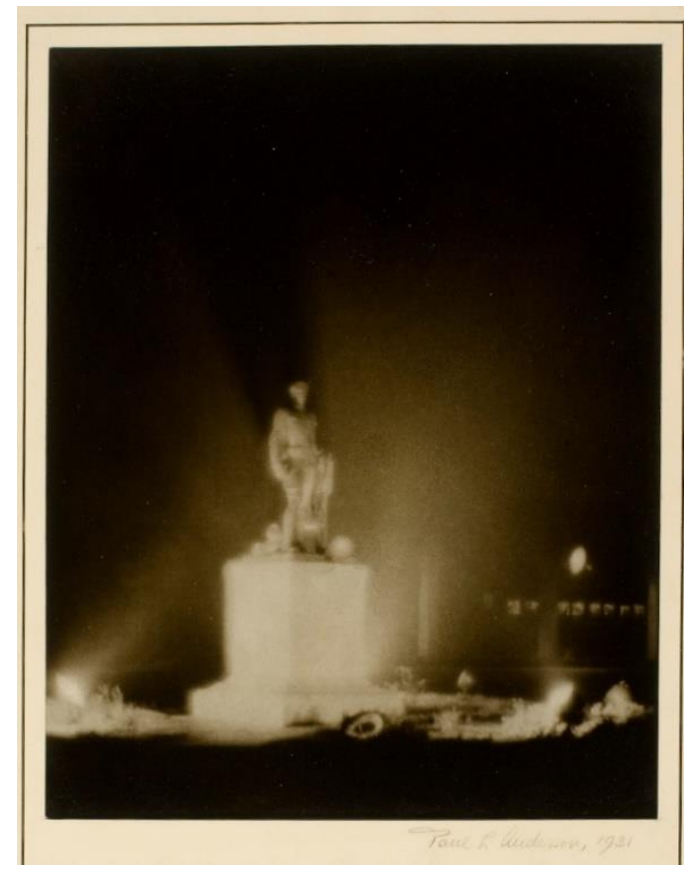

Figure 9 A carbro print (1976.0315.0050) 


\section{Photomechanical Processes}

Photogravure: This is a photomechanical process related to the intaglio, aquatint process, where a photographic image is chemically etched into a copper printing plate that can be run through a press to produce high quality prints with high quality ink. The process relies on the hardening principle of dichromated gelatin. A sheet of dichromated gelatin is exposed in contact with a positive transparency, the tissue is put in contact with the copper plate that was dusted with acidresist resin grains (which give the print the appearance of continuous tone). The tissue and plate are placed in warm water and the tissue is peeled away, with the gelatin transferring to the plate. The plate is than washed in warm water and the unexposed gelatin is washed away. Then the plate is put into a series of acid baths that etch the plate in relation to the thickness of the gelatin. The acid bites into the plate creating pits that can be inked and printed onto a piece of paper. There are two photogravures in the Anderson photographs (1976.0315.0318, 0424). One (Portrait of Henry R. Poore, 0424) was mostly likely made because it also appears as a frontispiece in his book Pictorial Photography: Its Principles and Practice.

\section{Color Processes}

Hess-Ives (Hicrography or Hichrome): This was an early dye imbibition process that was impractical and never really became widespread. It required its own camera and special pack of film. Through red, blue, and green filters and a series of mirrors it exposed 3 black and white negatives to record red, blue, and green light. These negatives were developed and positive impressions of these were made on proprietary dichromated film. The unhardened gelatin was washed away, and these matrices were then dyed in a peacock blue, magenta, and yellow dye. These dyed matrices were transferred, in registration, to a sheet of paper. The dyes in the finished print were not very stable over time, but produced pleasing tones. Anderson has one example of the process: a portrait of his daughter Pinkie, which is badly deteriorated.

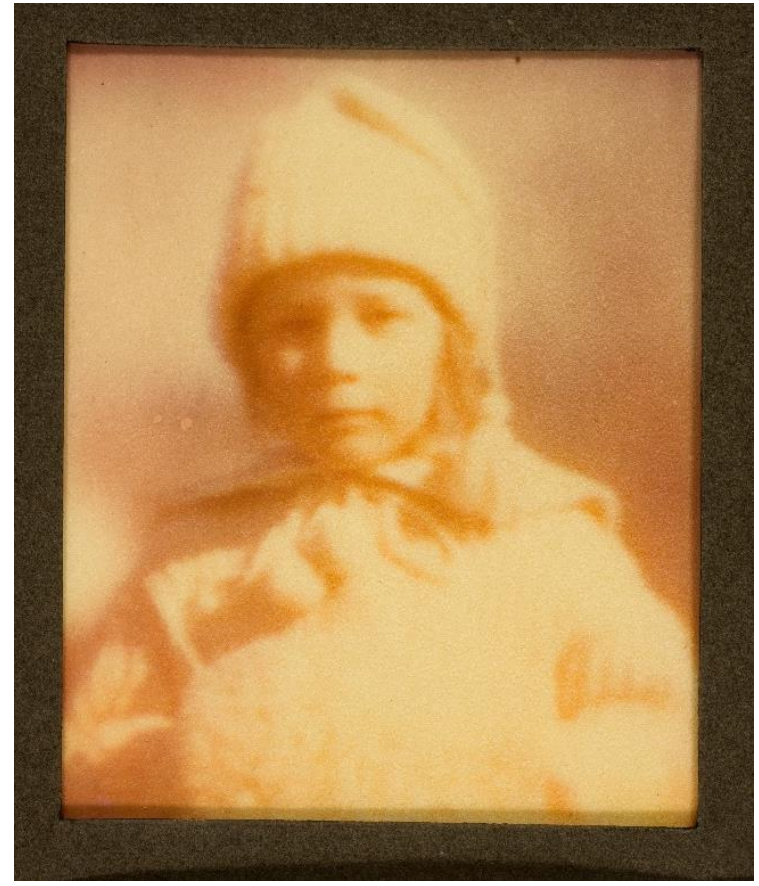

Figure 12 A Hess-Ives print or Hichrome (1976.0315.0482)

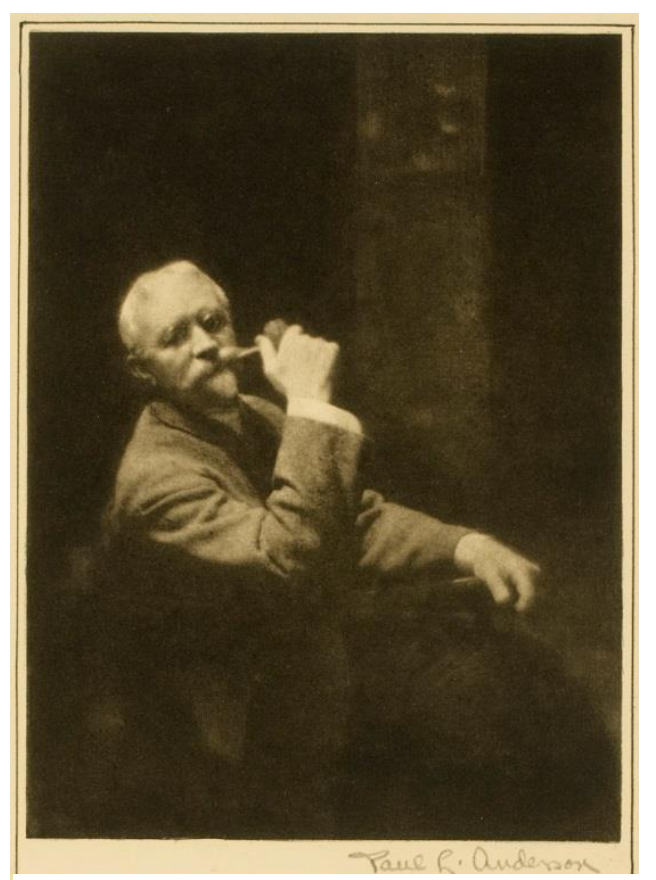

Figure 11 A photogravure print (1976.0315.0424) 


\section{Section 4: Characteristic Inscriptions}

Inscriptions on the rectos of prints come in three elements: his signature, the date, or a stylized colophon. Anderson almost always signs his prints (although there are unsigned examples, where the signature is on the verso). This is done is a few different ways: he either wrote Paul Lewis Anderson, Anderson, or P.L.A., in pencil on the lower margin of the print, or in some cases on the mounting board, or in the image itself. Usually next to his signature he dates the print. This can be either single year, a range of one or two years, or a range of many years. The final element that appears especially in the early years of his career is the stylized colophon. This consist of his initials and the date in a decorative fashion.

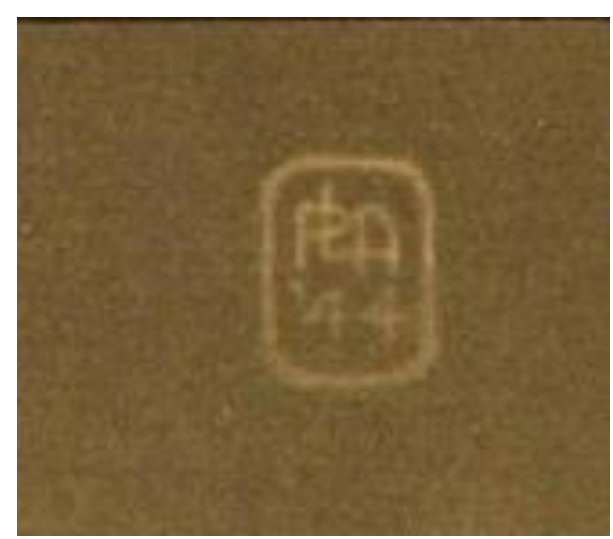

Figure 13 Example of Colophon 1976.0315 .0043

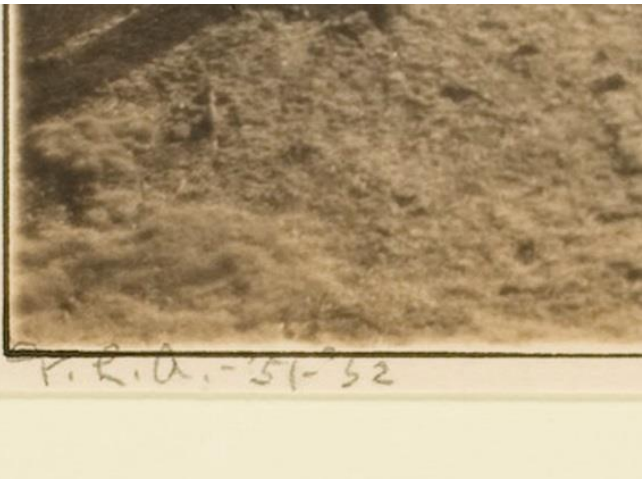

Figure 15 Example of signature and date range 1976.0315.0017

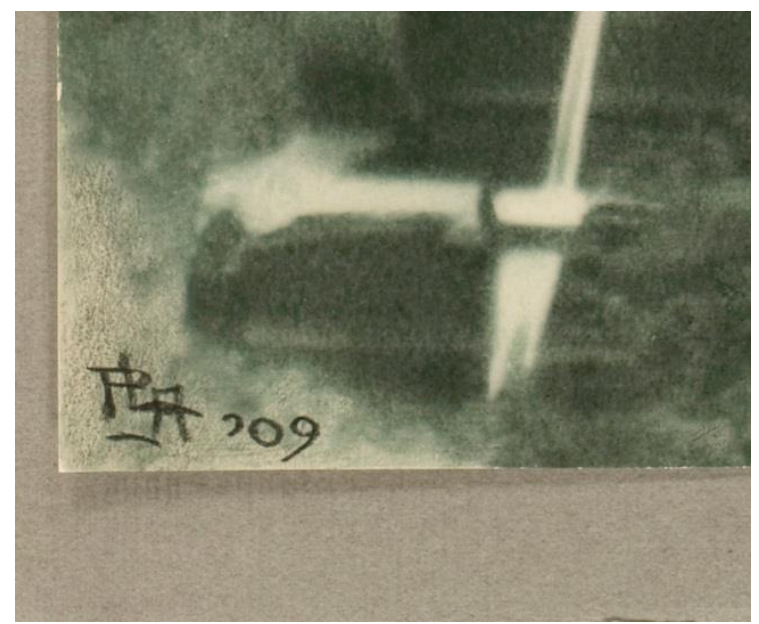

Figure 14 Example of a Colophon 1976.0315.0361

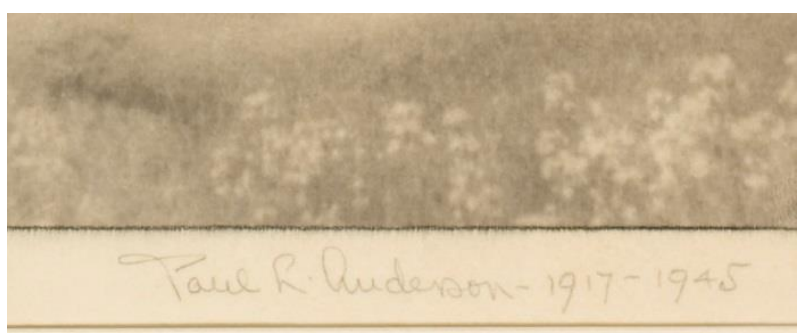

Figure 16 Example of signature and date range 1976.0315 .0318

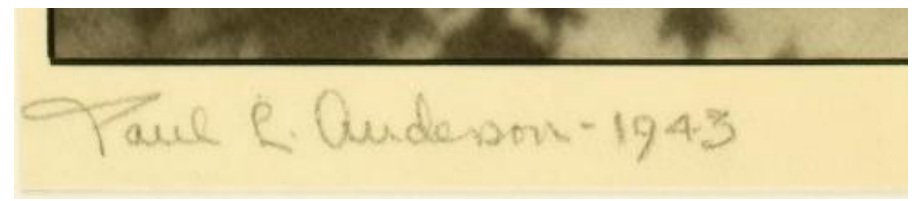

Figure 17 Example of signature and single date 1977.0315.0329 
Inscriptions on the versos are located either on the verso of the print or, in most cases, on the mount. These can include multiple different types of information. As far as signatures, if the print is not signed on the recto it is signed on the verso usually in pencil and with Anderson's initials. The most common type of information on the verso is a typed label that lists the title of the work, Anderson's address, and the medium of the print. This is sometimes written in pencil, but in the same fashion as the typed label (sometimes with or without his address). He also sometimes includes a postage-sized label that just lists his name and the address. Another aspect of his versos are ribbons and labels from camera clubs around the United States and Europe. These vary in geographic location, year, colour, and complexity in design and typography.

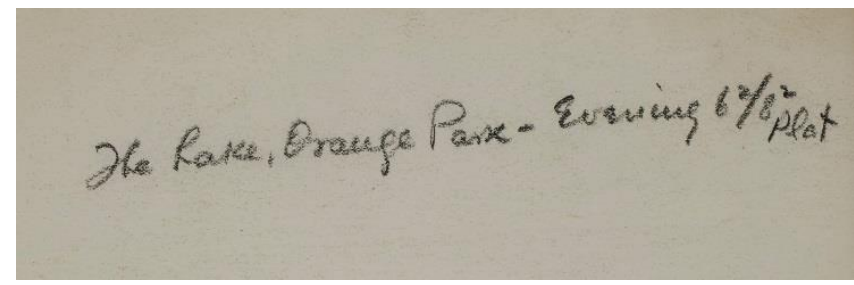

Figure 18 Example of pencil inscription on verso 1976.0315.0010

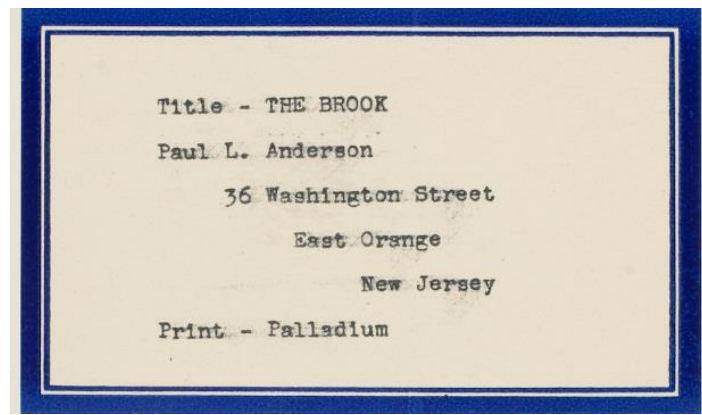

Figure 17 Example of typed label 1976.0315.0003

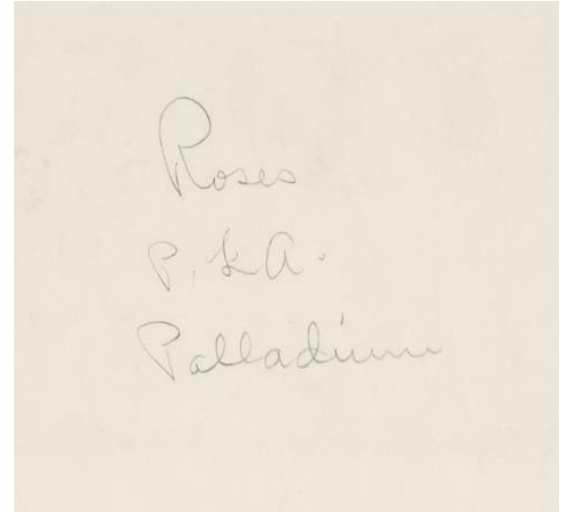

Figure 20 Example of pencil inscription 1976.0315 .0343

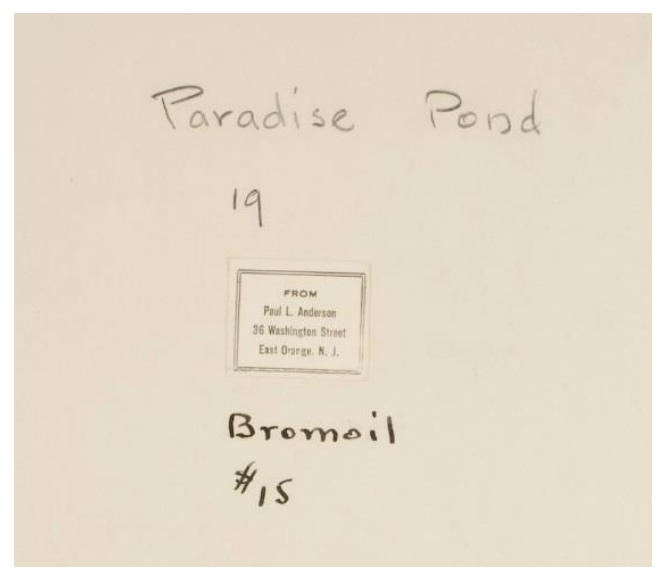

Figure 22 Example of pencil and ink inscriptions, and small address label 1976.0315.0126

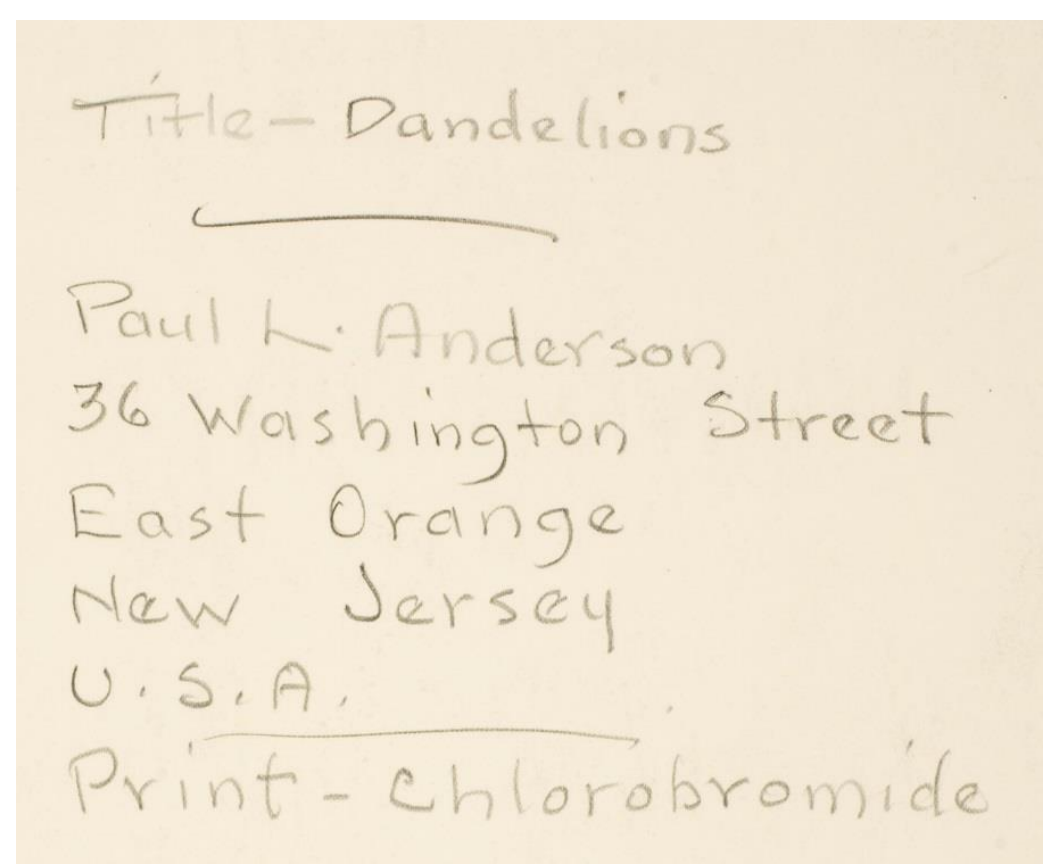

Figure 21 Example of pencil inscription listing title, address, and medium 1976.0315 .0357 


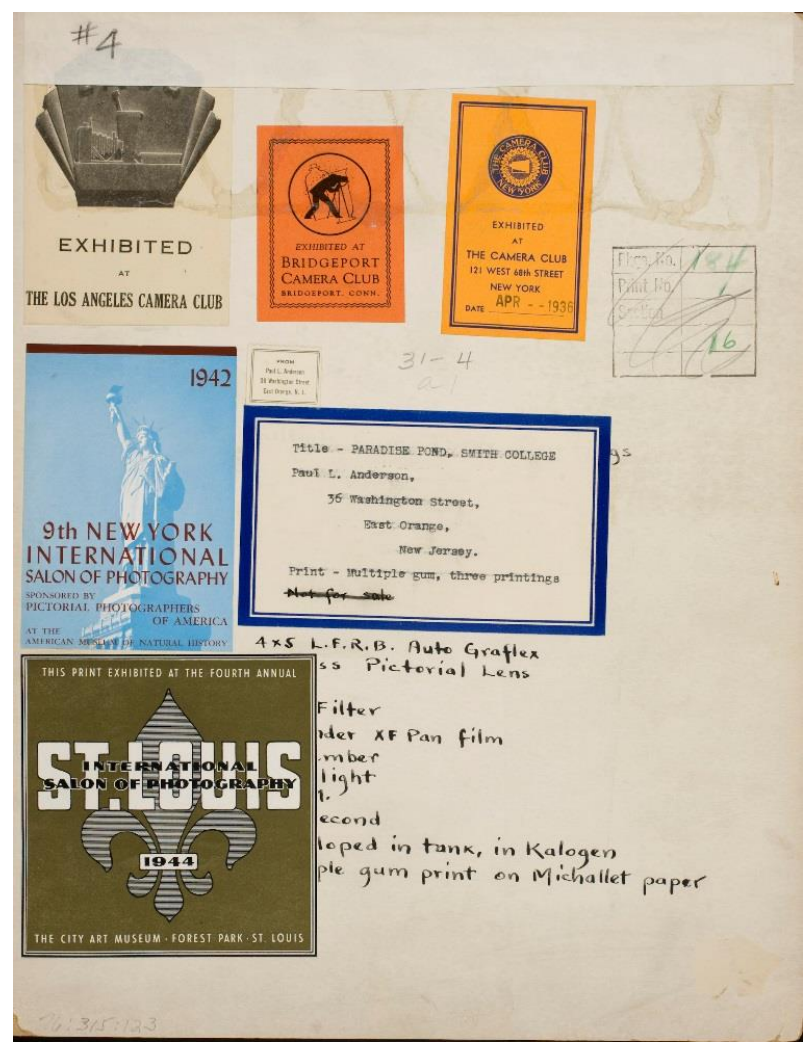

Figure 23 Example of different camera club ribbons, typed label, and technical information 1976.0315.0123

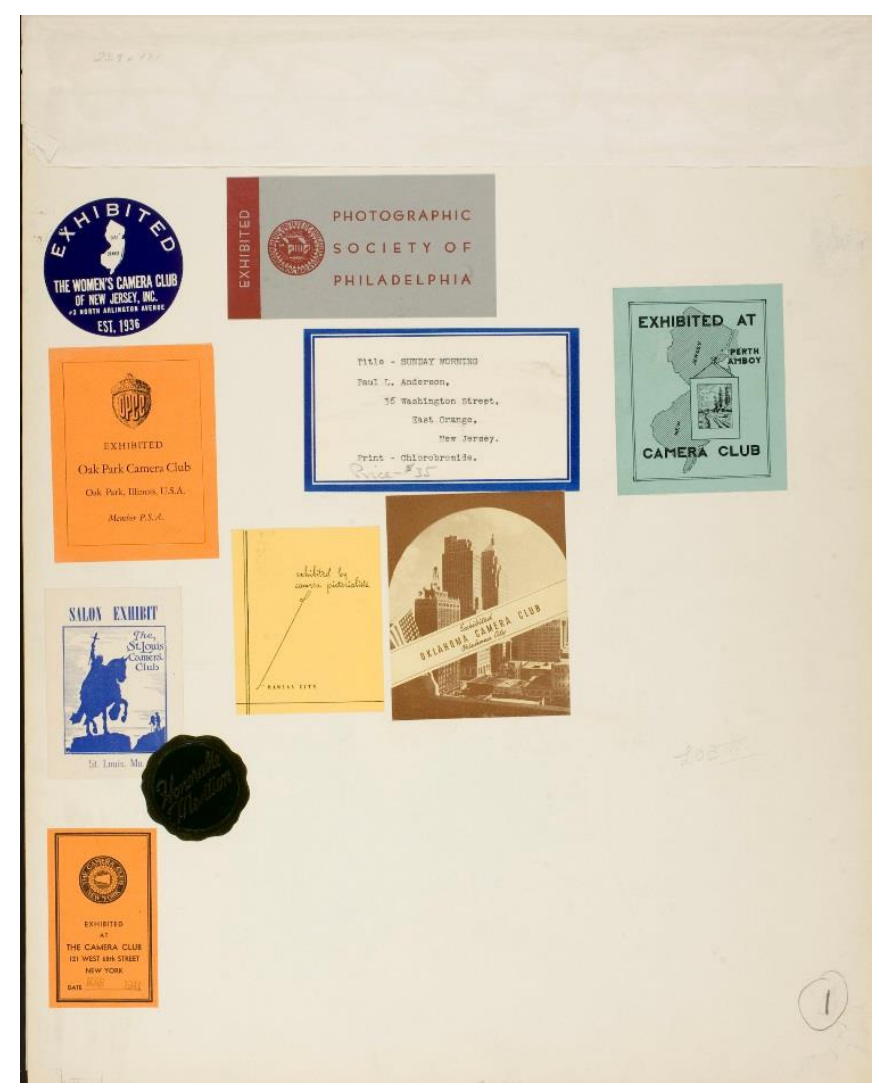

Figure 25 Example of different camera club ribbons with different designs and colors 1976.0315.0326 


\section{Section 5: Selected Paul Lewis Anderson Bibliography}

This bibliography lists a selection of Anderson's writings on process, his critiques, and his other writings. It also lists the recent secondary sources related to Anderson.

Books

Anderson, Paul Lewis. Pictorial Landscape-Photography. Boston: Wilfred A. French, 1914 ------. Pictorial Photography: Its Principles and Practices. Philadelphia: J.P. Lippincott, 1917.

[Revised and reissued in 1923 and 1934]

-----. The Fine Art of Photography. Philadelphia: J.P. Lippincott, 1919.

-----. The Technique of Pictorial Photography. Philadelphia: J.P. Lippincott, 1939.

Articles on Process

Anderson, Paul Lewis. “Sensitizing Platinum Paper.” American Annual of Photography 1912 (1911), 45-52.

------. “Oil and Bromoil for Portraiture.” American Annual of Photography 1917 (1916), 244-49.

------. "The Hess-Ives Process of Color Photography.” American Annual of Photography 1918 (1917), 56-63.

-----. “Carbon and Carbro for Portraiture.” American Annual of Photography 1923 (1922), 4050.

------. "The Gum Pigment Process - Part I (General Character and Theory)." The Camera 50.4 (April 1935), 217-22.

------. “The Gum Pigment Process - Part II (Type of Negative and Paper)." The Camera 50.5 (May 1935), 292-96.

------ "The Gum Pigment Process - Part III (Ingredients and Implements)." The Camera 50.6 (June 1935), 361-65.

------ "The Gum Pigment Process - Part IV (Coating Paper).” The Camera 51.1 (July 1935), 5-8.

-----. "The Gum Pigment Process - Part V (Printing and Developing)." The Camera 51.2 (August 1935), 73-77.

------. “The Gum Pigment Process - Part VI (General Remarks).” The Camera 51.3 (September 1935), 145-51.

Critical and Historical Articles

Anderson, Paul Lewis. "Values.” American Annual of Photography 1926 (1925), 132-43.

-----. "Modernistic Reactionaries.” American Photography 27.1 (January 1933), 30-40.

------. "Thoughts on Modern Photography." The Camera 48.3 (March 1934), 145-56.

-----. "Some Pictorial History.” American Photography 29.4 (April 1935), 199-214.

-----. "The Rationale of Pictorial Composition." American Annual of Photography 1939 (1938), 7-14.

------. "Superstition in Photography.” American Photography 33.4 (April 1939), 241-52.

Secondary Sources

Peterson, Christian A. "Paul Lewis Anderson: Photographer of Light," Bulletin of the Detroit Institute of the Arts 84.1 (2010), 17.

Pitts, Terence R. "Paul Lewis Anderson: A Life in Photography." The Archive 18 (May 1983): 414. 


\section{BIBLIOGRAPHY}

\section{Books}

A History of Photography: 1839 to the Present. Edited by Therese Mulligan and David Wooters New York: Taschen, 2008.

Anderson, Paul Lewis. Pictorial Photography: Its Principles and Practices. Philadelphia: J.P. Lippincott, 1922.

Anderson, Paul Lewis. The Technique of Pictorial Photography. Philadelphia: J.P Lippincott, 1939.

Bender, Donna Paul Anderson: Photographs. Tucson: Center for Creative Photography, 1983.

Kennel, Sarah. In the Darkroom: An Illustrated Guide to Photographic Processes before the Digital Age. Washington: National Gallery of Art, 2009.

Lavedrine, Bertrand. Photographs of the Past: Process and Preservation. Los Angeles: Getty Conservation Institute, 2009.

Nadeau, Luis. History and Practice of Oil and Bromoil printing. Fredericton, NB: Atelier Luis Nadeau, 1985.

Nordstrom, Alison and Thomas Padon, Truth/Beauty: Pictorialism and the Photograph as Art, 1845-1945. Vancouver: Vancouver Art Gallery, 2008.

Peterson, Christian A. After the Photo-Secession: American Pictorial Photography 1910-1955. New York: W.W. Norton \& Company, 1997.

Society of American Archivists. Describing Archives: A Content Standard. Chicago: SAA, 2013.

Sullivan, Dick. The Bostick \& Sullivan Book of Modern Carbon Printing. Santa Fe: The Bostick \& Sullivan Press, 2007.

Yochelson, Bonnie and Kathleen A. Erwin. Pictorialism into Modernism: The Clarence H. White School of Photography. Edited by Marianne Fulton. New York: Rizzoli, 1996.

\section{Dissertation}

Griffin, Michael S., Amateur Photography and Pictorial Aesthetics: Influences of Organizations and Industry on Cultural Production, PhD Dissertation, University of Pennsylvania, 1987.

\section{Articles}

“Art and Its Masters,” Review of Reviews 61.1 (January 1920), 110. 
"Paul Lewis Anderson: Photograph Collection," (An alphabetical index to the photographs in the Center for Creative Photography Photograph Collection organized by name of photographer). Tucson: Center for Creative Photography, 2001.

Cohen, Susan E. “Recent Acquisitions: Paul Lewis Anderson (1880-1956)," Image 22.2 (June 1979), 15.

Johnson, Ken "No Detail Goes Unnoticed When Art Is a Click Away," The New York Times January 29, 2015.

Martenstyn, Lynsey "Digital archives: making museum collections available to everyone." The Guardian May 3, 2013.

Obituaries, The New York Times, September 17, 1956.

Peterson, Christian A. "Paul Lewis Anderson: Photographer of Light," Bulletin of the Detroit Institute of the Arts 84.1 (2010), 17.

Pitts, Terence R. "Paul Lewis Anderson: A Life in Photography." The Archive 18 (May 1983): 414.

\section{Webpages}

Center for Creative Photography. "Paul Lewis Anderson.” Accessed June 14, 2015, http://www.creativephotography.org/artists/paul-l-anderson

Eastman House. "Vision and Mission." Accessed June 14, 2015. http://www.eastmanhouse.org/museum/mission.php

Image Permanence Institute. “Graphics Atlas.” Accessed June 14, 2015, http://www.graphicsatlas.org/

Museum of Modern Art. “Object Photo.” Accessed June 14, 2015. http://www.moma.org/interactives/objectphoto/

Yochelson, Bonnie "The Clarence H. White School of Photography," in Object:Photo. Modern Photographs: The Thomas Walther Collection 1909-1949. An Online Project of The Museum of Modern Art. Edited by Mitra Abbaspour, Lee Ann Daffner, and Maria Morris Hambourg. New York: The Museum of Modern Art, 2014. http://www.moma.org/interactives/objectphoto/assets/essays/Yochelson.pdf 